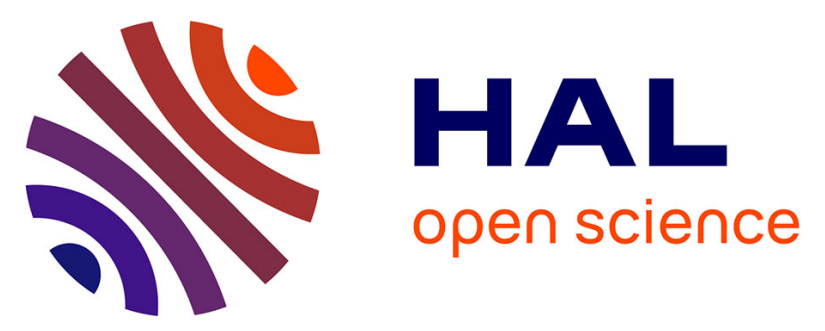

\title{
Cadomian S-type granites as basement rocks of the Variscan belt (Massif Central, France): Implications for the crustal evolution of the north Gondwana margin
}

Simon Couzinié, Oscar Laurent, Marc Poujol, Michaël Mintrone, Cyril Chelle-Michou, Jean-François Moyen, Pierre Bouilhol, Adrien Vezinet, Linda Marko

\section{To cite this version:}

Simon Couzinié, Oscar Laurent, Marc Poujol, Michaël Mintrone, Cyril Chelle-Michou, et al.. Cadomian S-type granites as basement rocks of the Variscan belt (Massif Central, France): Implications for the crustal evolution of the north Gondwana margin. Lithos, 2017, 286-287, pp.16-34. 10.1016/j.lithos.2017.06.001 . hal-02934780

\author{
HAL Id: hal-02934780 \\ https://hal.science/hal-02934780
}

Submitted on 10 Sep 2020

HAL is a multi-disciplinary open access archive for the deposit and dissemination of scientific research documents, whether they are published or not. The documents may come from teaching and research institutions in France or abroad, or from public or private research centers.
L'archive ouverte pluridisciplinaire HAL, est destinée au dépôt et à la diffusion de documents scientifiques de niveau recherche, publiés ou non, émanant des établissements d'enseignement et de recherche français ou étrangers, des laboratoires publics ou privés. 
Couzinié, S., Laurent, O., Poujol, M., Mintrone, M., Chelle-Michou, C., Moyen, J. F., Bouilhol, P., Vezinet, A., \& Marko, L. (2017). Cadomian S-type granites as basement rocks of the Variscan belt (Massif Central, France): Implications for the crustal evolution of the north Gondwana margin. Lithos, 286-287, 16-34. https://doi.org/10.1016/j.lithos.2017.06.001

Peer reviewed version

Link to published version (if available):

10.1016/j.lithos.2017.06.001

Link to publication record in Explore Bristol Research

PDF-document

This is the author accepted manuscript (AAM). The final published version (version of record) is available online via ELSEVIER at http://www.sciencedirect.com/science/article/pii/S0024493717301986?via\%3Dihub. Please refer to any applicable terms of use of the publisher.

\section{University of Bristol - Explore Bristol Research}

General rights

This document is made available in accordance with publisher policies. Please cite only the published version using the reference above. Full terms of use are available: http://www.bristol.ac.uk/pure/user-guides/explore-bristol-research/ebr-terms/ 


\title{
Cadomian S-type granites as basement rocks of the Variscan belt (Massif Central, France): implications for the crustal evolution of the north Gondwana margin
}

\author{
Simon Couzinié ${ }^{1,2}$, Oscar Laurent ${ }^{3,7}$, Marc Poujol ${ }^{4}$, Michaël Mintrone ${ }^{1,7}$, Cyril Chelle- \\ Michou $^{1,9}$, Jean-François Moyen ${ }^{1}$, Pierre Bouilhol ${ }^{5,8}$, Adrien Vezinet ${ }^{1,2}$, Linda Marko ${ }^{6}$ \\ ${ }^{1}$ Université de Lyon, Laboratoire Magmas et Volcans, UJM-UCA-CNRS-IRD, 23 rue du Dr. Paul Michelon, \\ 42023 Saint-Etienne, France. Corresponding author: simon.couzinie@univ-st-etienne.fr or \\ simon.couzinie@ens-lyon.org \\ ${ }^{2}$ University of Stellenbosch, Department of Earth Sciences, Private Bag X1, 7602 Matieland, South Africa \\ ${ }^{3}$ Université de Liège, Département de Géologie B20, Quartier Agora, allée du six Août 12, B-4000 Liège, \\ Belgium \\ ${ }^{4}$ Géosciences Rennes, UMR-CNRS 6118, Université de Rennes I, 35042 Rennes Cedex, France \\ ${ }^{5}$ Department of Earth Sciences, Durham University, Science Labs, Durham DH13LE, United Kingdom \\ ${ }^{6}$ Institut für Geowissenschaften, J.W. Goethe Universität, Altenhöferallee 1, 60438 Frankfurt Am Main, \\ Germany \\ ${ }^{7}$ Now at Institute for Geochemistry and Petrology, ETH Zürich, Zurich, Switzerland \\ ${ }^{8}$ Now at Laboratoire Magmas et Volcans, Université Clermont Auvergne-CNRS-IRD, OPGC, Campus \\ Universitaire des Cézeaux, 6 Avenue Blaise Pascal, 63178 Aubière Cedex, France \\ ${ }^{9}$ Now at School of Earth Sciences, University of Bristol, Bristol BS8 1RJ, UK.
}

\begin{abstract}
From the Neoproterozoic to the early Paleozoic, the northern Gondwana margin was sequentially shaped by the Cadomian accretionary and the Variscan collisional orogens which offers the opportunity to investigate the relative extent of crust production/reworking in both geodynamic settings. In the eastern part of the Variscan French Massif Central (FMC), the Velay Orthogneiss Formation (VOF) represents a consistent lithological unit of the pre-Variscan basement and comprises augen gneisses and leucogneisses. Such rocks constitute a unique record of the preVariscan magmatic history and bear critical information on the crustal evolution of the northern Gondwana margin.
\end{abstract}


Here, we present whole-rock major and trace element compositions indicating that: (i) the VOF shows a remarkable geochemical homogeneity; (ii) the protolith of the augen gneisses corresponds to strongly peraluminous, "S-type" porphyritic granites originating from partial melting of an Ediacaran sedimentary sequence; (iii) the leucogneisses are former leucogranites generated by fractionation of the magma at the origin of the porphyritic granites; and (iv) the whole suite emplaced at shallow crustal levels $(<7 \mathrm{~km})$. U-Pb LA-(MC-)ICP-MS analyses on zircon yielded similar emplacement ages of c. $542 \mathrm{Ma}$ and a narrow range of $\varepsilon_{\mathrm{Hf}}(\mathrm{t})$ clustering around 0 for the protoliths of both augen and leucogneisses. This homogeneous Hf isotope signature, notably uncommon for S-type granites, would originate from a sequential process of: (i) inherited zircon dissolution during melting and ascent in the crust due to Zr-undersaturated conditions, (ii) isotopic homogenization of the melt by advection and elemental/isotopic diffusion, followed by (iii) early saturation upon emplacement owing to rapid cooling at shallow crustal levels.

We propose that partial melting of Ediacaran sediments occurred during inversion of a Cadomian back-arc basin and was promoted by the high thermal gradient typical of thinned crust domains. Therefore, the VOF and other Cadomian S-type granitoids from the northern Gondwana margin are indicative of substantial crust reworking away from any proper continental collision zone.

\section{Keywords}

North Gondwana margin; Cadomian orogeny; Variscan orogeny; S-type granites; Lu-Hf isotopes; French Massif Central

\section{Introduction}

Accretionary orogens develop along oceanic and continental active margins, feature volumetrically abundant mantle-derived magmatism and are accordingly considered as the main locus of continental crust production (Cawood et al., 2009; Jagoutz and Kelemen, 2015; Reymer and Schubert, 1984; Taylor and McLennan, 1985). Conversely, collisional orogens juxtapose stable portions of continental lithospheric blocks and are rather seen as domains of extensive crust reworking through partial melting of pre-existing crustal rocks (Dewey et al., 1986; Harris et al., 1986; Hawkesworth et al., 2009, 2010). However, recent studies have refined and nuanced these 
end-member scenarios by pointing out that new crust may also be produced at the end of continental collision (Couzinié et al., 2016; Moyen et al., 2017; Niu et al., 2013) and likewise, that crust reworking also takes place in arc systems (Collins and Richards, 2008; Zurbriggen, 2015). Therefore, assessing the relative importance of each phenomenon in both geodynamic settings is paramount to understand the modes of continental crust formation and evolution through time.

Terranes formerly belonging to the northern Gondwana margin (Fig. 1, see review in Stampfli et al. (2013)) are ideal targets to address this issue because they have sequentially been affected by: (i) the Cadomian Western Pacific-type marginal orogenic system, of Cryogenian-Ediacaran age (Chelle-Michou et al., 2017; Garfunkel, 2015; Linnemann et al., 2014; Nance et al., 1991); followed by, (ii) the Variscan orogeny, a major late Paleozoic continental collision episode resulting from the convergence between Laurussia and Gondwana (Kroner and Romer, 2013; Matte, 1986) and culminating with the assembly of Pangea, the latest supercontinent of Earth's history (Rogers and Santosh, 2003).

The French Massif Central (FMC) shows one of the largest exposures of the inner part of the Variscan orogen (Lardeaux et al., 2014) and isotopic evidence from the voluminous Variscan crustderived granitoids demonstrate that such magmatism extensively reworked a continental crust of Neoproterozoic to early Paleozoic ancestry (Melleton et al., 2010; Moyen et al., 2017; Pin and Duthou, 1990; Turpin et al., 1990). However, the nature of this pre-Variscan crust as well as the geodynamic setting in which it formed are still a matter of debate. For instance, it remains unclear to what extent the crust segment today exposed in the FMC was impacted by the Cadomian orogeny (see discussion in Garfunkel (2015)). From this perspective, a better knowledge of the age, structure, lithological composition and configuration of the pre-Variscan crust in the FMC would: (i) provide new constraints on the late Ediacaran/early Paleozoic paleogeography and geodynamics of the northern Gondwana margin; (ii) improve our understanding of the rate and timing of crustal growth in Western Europe.

In the eastern part of the FMC, the Variscan nappes feature high-grade gneisses and, in particular, large amounts of meta-igneous rocks, which have likely witnessed one or several pre-Variscan magmatic episodes. Somewhat outdated radiometric dating from these orthogneisses (CaenVachette, 1979; R'Kha-Chaham et al., 1990) as well as detrital and inherited zircon data from metasedimentary rocks (Chelle-Michou et al., 2017) and Variscan granitoids (Laurent et al., 2017) 
respectively, suggest that they emplaced close to the Proterozoic-Paleozoic boundary at ca. 545 Ma. Yet, these meta-igneous rocks lack modern and/or direct geochronological data, in contrast to the western FMC where such work has been undertaken (Alexandre, 2007; Alexandrov et al., 2001; Melleton et al., 2010). Similarly, the nature, petrogenesis and geodynamic significance of the FMC orthogneisses are poorly constrained. The aim of this contribution is therefore to decipher the age and origin of the pre-Variscan orthogneiss units in the Velay area using field observations, wholerock geochemistry, LA-ICP-MS zircon $\mathrm{U}-\mathrm{Pb}$ dating and $\mathrm{LA}-\mathrm{MC}-\mathrm{ICP}-\mathrm{MS}$ zircon $\mathrm{Lu}-\mathrm{Hf}$ isotope measurements. This new dataset demonstrates that the pre-orogenic evolution of this part of the FMC is dominated by late Ediacaran events and features the emplacement at shallow crustal levels of a large $\left(\sim 1800 \mathrm{~km}^{2}\right)$ S-type granite batholith, most likely formed by melting of an Ediacaran back-arc supracrustal sequence at the end of the Cadomian orogeny. This pinpoints the importance of crust reworking in accretionary orogens, even in domains lacking significant volumes of ancient basement.

\section{Geological setting}

2.1 The French Massif Central and its pre-Variscan evolution

The French Massif Central displays a south-verging stack of metamorphic nappes built up from the early Devonian to the early Carboniferous and composed from top to bottom of (Faure et al. (2009b); Ledru et al. (1989) and references therein): (i) amphibolite- to greenschist-facies upper allochthonous units (UAU: Thiviers-Payzac, Leyme, Gartempe, St-Sernin-sur-Rance, Génis, Brévenne); (ii) the Upper Gneiss Unit (UGU) which comprises amphibolite- to granulite-facies ortho- and paragneisses and typically shows at its base a bimodal meta-igneous association ("Leptynite-Amphibolite Complex" or LAC) that contains relicts of eclogite-facies metamorphism; (iii) the Lower Gneiss Unit (LGU), an assemblage of amphibolite-facies micaschists, ortho- and paragneisses together with scarce amphibolites; (iv) the lower-grade Parautochthonous Unit (PAU) made up largely of greenschist- to amphibolite-facies meta-sediments (e.g. Cévennes schists); and (v) a Fold-and-Thrust Belt of very low metamorphic grade (Montagne Noire nappes, Vigan schists). The Variscan tectono-metamorphic evolution encompasses (Burg et al., 1994; Faure et al., 2009b): (i) an early (late Silurian to early Devonian) event corresponding to the closure of several oceanic domains and coeval HP metamorphism; (ii) late Devonian nappe stacking and crustal 
thickening ending up in the growth and lateral flow of an orogenic plateau during the early Carboniferous; (iii) gravitational collapse via the activation of low-angle detachment faults marked by the development of migmatite domes in the late Carboniferous.

The pre-Variscan sedimentary materials that build up the low-grade nappes (UAU, PAU and Foldand-Thrust Belt) are mostly late Ediacaran to early Ordovician in age as shown by paleontological data (Fournier-Vinas and Debat, 1970; Guérangé-Lozes and Burg, 1990; Reitz and Wickert, 1988) and dating of interlayered volcanics (Faure et al., 2009a; Lescuyer and Cocherie, 1992). In highergrade, gneissic units (UGU and LGU), detrital zircon studies (Chelle-Michou et al., 2017; Melleton et al., 2010) together with field relationships between meta-sediments and adjacent dated orthogneisses suggest maximum depositional ages ranging from the early Ediacaran to the Cambrian (Ledru et al., 1994; Melleton et al., 2010). The conspicuous presence of volcanic rocks (meta-tuffs, meta-lavas) throughout the stratigraphic pile exposed in low-grade units (Alvaro et al., 2014; Marini, 1987; Pouclet et al., 2017) and the existence of several orthogneiss massifs of similar ages within the high-grade domains (Alexandre, 2007; Duthou et al., 1984; Melleton et al., 2010; Roger et al., 2015) testify for a protracted magmatic activity from the late Ediacaran to the late Ordovician. Petrogenetic studies attest to the tapping of two contrasting reservoirs throughout this period: (i) the asthenospheric/lithospheric mantle, source of the metabasites from the low-grade units and the LAC (Briand et al., 1992; Marini, 1987; Pin and Marini, 1993; Pouclet et al., 2017); (ii) preexisting crustal lithologies (Alexandre, 2007; Melleton et al., 2010) as a source of felsic magmas. Coeval sedimentation, crust- and mantle-derived magmatism has been attributed to longlived continental extension ending up in the formation of a hyperextended margin during the Ordovician (Lardeaux et al., 2014). Collectively, these data suggest that the pre-Variscan crust of the FMC is not older than Neoproterozoic in age (Chelle-Michou et al., 2017).

\subsection{The Velay dome}

In the eastern Massif Central, the Variscan nappe stack (and notably the LGU; Fig. 3) is reworked by the formation of a $120 \times 80 \mathrm{~km}$ granite-migmatite complex, referred to as the Velay dome. It corresponds to partially molten middle crust which exhumation was controlled on its northern edge by the Pilat low-angle detachment shear zone, typically showing top-to-the-NE sense of shear dated at $313 \pm 6 \mathrm{Ma}$ by ${ }^{39} \mathrm{Ar} /{ }^{40} \mathrm{Ar}$ on syntectonic biotite (Gardien et al., 1997; Malavielle et al., 1990). On its southern edge, the dome is overturned to the south (Lagarde and Dallain, 1994) onto the 
PAU, from which it is separated by a top-to-the south normal shear zone dated at $310 \pm 5 \mathrm{Ma}$ (Bouilhol et al., 2006). The Velay Dome consists of several lithologies including (Fig. 1): (i) orthoand paragneisses ranging from unmolten to diatexitic (Montel et al., 1992) together with very scarce amphibolites (Briand et al., 1992); (ii) a set of peraluminous granitoids comprising early laccoliths (Ledru et al., 2001) and the heterogeneous biotite-cordierite-bearing "Velay" granite (Williamson et al., 1992). The migmatites and associated granites result from several successive melting events (Montel et al., 1992) over a period of 35 Ma, from c. 335 to $300 \mathrm{Ma}$ (Couzinié et al., 2014; Laurent et al., 2017).

Here we define the Velay Orthogneiss Formation (VOF) as a consistent lithological unit gathering all pre-Variscan meta-igneous felsic rocks that crop out in the dome. The VOF can be divided into three main geographic sub-domains (Fig. 2): (i) the Pilat orthogneisses, exposed along the northeastern part of the dome; (ii) the Vivarais area, where meta-igneous rocks and paragneisses represent the weakly molten roof of the dome (Lagarde and Dallain, 1994); (iii) the "Arc-de-Fix" orthogneisses (R'Kha Chaham et al., 1990), which form a crescent outlining the western and southern parts of the dome. Collectively, the VOF covers an exposed area of $\sim 1800 \mathrm{~km}^{2}$. Field observations show that the VOF is intrusive within the adjacent paragneisses (Ledru et al., 1994, Fig. 3).

Typical lithologies of the VOF are (based on our field survey and unpublished French $\mathrm{PhD}$ theses from the $70 \mathrm{~s}-80 \mathrm{~s}$, referenced in Supplementary text): (i) a volumetrically dominant biotite \pm muscovite \pm sillimanite augen gneiss (Fig. 4a) featuring pluricentimetric K-feldspar porphyroblasts and accessory garnet, allanite, ilmenite, apatite and zircon; (ii) a muscovite \pm biotite \pm garnet fine-grained leucogneiss (locally called "leptynite") with similar accessory minerals; (iii) a volumetrically subordinate biotite \pm cordierite/garnet medium-grained banded orthogneiss. The leucogneisses occasionally occur as pluri-metric enclaves or boudins within the augen gneiss (Fig. 4b), but most often form concordant bodies embedded within it (Fig. 4c,d). The contact between both lithologies can be sharp and locally underlined by a thin biotite selvage (Fig 4c), or gradational, in which case leucogneisses appear as counterparts of the augen gneisses lacking biotite and K-feldspar porphyroblasts. All rock types are deformed by the Variscan tectonics, especially the augen gneiss that shows a well-developed foliation locally up to mylonitic grade (Fig. 4d), and locally display evidence for partial melting such as disruption of the foliation 
associated with segregation of leucosomes (especially close to the margins and at the roof of the Velay dome). The Vivarais gneisses tend to be more migmatitic (metatexite to diatexite) than the Arc-de-Fix (typically unmolten to metatexitic).

Studies on the VOF have concluded that augen gneisses in the Arc de Fix, Vivarais and Pilat domains correspond to former porphyritic granitoids (Ledru et al., 2001). Previous geochronological investigations suggest that those granitoids were emplaced in the early Cambrian as the Arc-de-Fix gneisses yielded a zircon Pb evaporation age of $533 \pm 23 \mathrm{Ma}$ (Mougeot et al., 1997) and a whole-rock Rb-Sr age of $528 \pm 9 \mathrm{Ma}$ (R'Kha Chaham et al., 1990). EPMA dating of inherited monazites in a migmatitic augen gneiss yielded similar results (543 $\pm 25 \mathrm{Ma}$; Be Mezeme et al. (2006)). The origin and age of leucogneisses are still disputed. In the Arc-de-Fix domain, they are thought to be part of the same magmatic suite of the augen gneiss protolith and would thus correspond to early Cambrian meta-leucogranites (R'Kha Chaham et al., 1990). In the Vivarais area, Chenevoy et al. (1986) also proposed a leucogranite protolith. In the Pilat domains, leucogneisses are rather regarded as former rhyolites or rhyolitic tuffs of late Ediacaran age (545 \pm $14 \mathrm{Ma}$; Caen-Vachette (1979)).

\section{Materials and methods}

\subsection{Whole-rock geochemistry}

We collected 35 samples of unmolten augen gneisses, banded gneisses and leucogneisses from the three domains mentioned above. Location, GPS coordinates and description of investigated samples are presented Table S1. Whole-rock major and trace element contents were obtained from the ALS Global firm (details on the procedure and accuracy/reproducibility in Supplementary text). A database of VOF samples was compiled using this new dataset and analyses from the literature (see Table S2), carefully filtering out: (i) migmatitic samples, based on petrographic descriptions; and (ii) samples that experienced alteration and/or LILE (Large Ion Lithophile Elements) mobility during Variscan metamorphism, by calculating the weathering index (W) of Ohta and Arai (2007) and considering a cut-off value of $\mathrm{W}=30 \%$ ( see Supplementary text). A total of 270 major-elements analyses were retained accordingly (including the newly obtained data). We will further consider that the retained VOF samples experienced nearly closed-system metamorphism during the Variscan orogeny, such that their chemical compositions reflect those of their igneous protoliths. 
This assumption is supported by (i) their position close to, or overlapping with the "igneous trend" in the MFW diagram of Ohta and Arai (2007), suggesting limited element mobility; and (ii) the fact that 22 samples from the VOF analyzed for Rb-Sr isotopes (Caen-Vachette (1979) and R'Kha Chaham et al. (1990)) define a whole-rock isochron clearly yielding a pre-Variscan (Cambrian) date (see Supplementary text and Fig. S2), specifically identical (within uncertainties) to our zircon $\mathrm{U}-\mathrm{Pb}$ dating results (see section 4.2).

\subsection{U-Pb geochronology}

We selected four samples from the VOF for $\mathrm{U}-\mathrm{Pb}$ dating, to constrain the age(s) of the igneous protolith(s). In this perspective, we focused the sampling in the Arc de Fix domain (Fig. 2) that is the least affected by the Variscan anatexis. Dated samples correspond to two augen gneisses (MM06 and MM11) and two leucogneisses (MM09 and MM10) representative of the main facies observed in the VOF. Their textures range from granoblastic to grano-lepidoblastic and porphyroclastic (for the augen gneisses, see Fig. 4a and c). Mineralogical assemblages are described Table 1 and representative annotated thin section photomicrographs can be found in the Supplementary material (Fig. S3).

Rock samples were crushed using standard procedures (jaw crusher, ring mill) and sieved to $<500$ $\mu \mathrm{m}$. Zircons were concentrated using conventional techniques (panning, heavy liquids, magnetic separation) and hand-picked under a binocular microscope. Selected grains were subsequently cast in epoxy resin and polished to expose their interiors. The internal structures were characterized by back-scattered electron (BSE) and cathodoluminescence (CL) imaging using (i) a Jeol JSM-6400 SEM at the Ecole des Mines de St-Etienne for BSE and (ii) a Jeol JSM-5910 SEM at the Laboratoire Magmas et Volcans (Clermont-Ferrand) for CL.

$\mathrm{U}-\mathrm{Pb}$ geochronology was conducted by in-situ laser ablation inductively coupled plasma mass spectrometry (LA-ICP-MS) at Géosciences Rennes using a ESI NWR193UC Excimer laser coupled to a quadrupole Agilent 7700x ICP-MS equipped with a dual pumping system to enhance sensitivity. The instrumental conditions are reported in Table S3.

The ablated material was carried into helium, and then admixed with nitrogen (Paquette et al., 2014) and argon, before injection into the plasma source. The alignment of the instrument and mass calibration was performed before each analytical session using the NIST SRM 612 reference glass, 
by inspecting the ${ }^{238} \mathrm{U}$ signal and by minimizing the $\mathrm{ThO}^{+} / \mathrm{Th}^{+}$ratio $(<0.5 \%)$. During the course of an analysis, the signals of ${ }^{204}(\mathrm{~Pb}+\mathrm{Hg}),{ }^{206} \mathrm{~Pb},{ }^{207} \mathrm{~Pb},{ }^{208} \mathrm{~Pb}$ and ${ }^{238} \mathrm{U}$ masses are acquired. The occurrence of common $\mathrm{Pb}$ in the sample can be monitored by the evolution of the ${ }^{204}(\mathrm{~Pb}+\mathrm{Hg})$ signal intensity, but no common $\mathrm{Pb}$ correction was applied owing to the large isobaric interference with Hg. The ${ }^{235} \mathrm{U}$ signal is calculated from ${ }^{238} \mathrm{U}$ on the basis of the ratio ${ }^{238} \mathrm{U} /{ }^{235} \mathrm{U}=137.88$. Single analyses consisted of $20 \mathrm{~s}$ of background integration followed by $60 \mathrm{~s}$ integration with the laser firing and then a $10 \mathrm{~s}$ wash-out delay. Ablation spot diameters of 20-35 $\mu \mathrm{m}$ with repetition rates of $3 \mathrm{~Hz}$ were used depending on the grain size. Data were corrected for $\mathrm{U}-\mathrm{Pb}$ and $\mathrm{Th}-\mathrm{Pb}$ fractionation and for mass bias by standard bracketing with repeated measurements of the GJ-1 zircon standard (Jackson et al., 2004). Along with the unknowns, the zircon standard Plešovice (337.13 $\pm 0.37 \mathrm{Ma}$, Sláma et al. (2008)) was measured to monitor accuracy of the analyses and produced a Concordia age of $337.0 \pm 1.8 \mathrm{Ma}\left(\mathrm{N}=20, \mathrm{MSWD}_{\mathrm{C}+\mathrm{E}}=0.21\right)$. Data reduction was carried out with the GLITTER ${ }^{\circledR}$ software package developed by the Macquarie Research Ltd. (Van Achterbergh et al., 2001). Concordia ages and diagrams were generated using Isoplot/Ex (Ludwig, 2008). Further information on the protocol can be found in Ballouard et al. (2015). The full set of results is available as Supplementary material (Table S4 for standards and S5 for samples).

\subsection{Zircon $\mathrm{Lu}-\mathrm{Hf}$ isotope determination}

Measurements were performed on magmatic zircons previously analyzed for $\mathrm{U}-\mathrm{Pb}$ dating at GUF, using a Thermo-Finnigan Neptune multicollector ICP-MS attached to a Resolution M-50 $193 \mathrm{~nm}$ Ar-F excimer laser ablation system, equipped with a two-volume Laurin Technic ablation cell. Laser spots with diameters of 40 or $60 \mu \mathrm{m}$ were drilled "on top" of the existing spots already analyzed for $\mathrm{U}-\mathrm{Pb}$ dating or in the same domain as identified on the basis of CL images (Fig. 5), with repetition rates of $4 \mathrm{~Hz}$ and an energy density of 5 to $6 \mathrm{~J} . \mathrm{cm}^{-2}$. He was used as a carrier gas $\left(\sim 0.6 \mathrm{~L} \cdot \mathrm{min}^{-1}\right)$ and make-up gas consisting of high-purity $\operatorname{Ar}\left(\sim 0.75 \mathrm{~L} \cdot \mathrm{min}^{-1}\right)$ and $\mathrm{N}_{2}\left(\sim 0.07 \mathrm{~L} \cdot \mathrm{min}^{-}\right.$ $\left.{ }^{1}\right)$ was admixed to the carrier gas to improve sensitivity. Post-ablation homogenization is performed by fluxing the gases through a Resolution Instruments Squid® tubing. Data were acquired using multi-collector static mode, during $58 \mathrm{~s}$ of measurement characterized by $1.052 \mathrm{~s}$ integration time (55 baseline-corrected ratios). ${ }^{172} \mathrm{Yb},{ }^{173} \mathrm{Yb}$ and ${ }^{175} \mathrm{Lu}$ masses were monitored to allow the correction of isobaric interferences $\left({ }^{176} \mathrm{Yb}\right.$ and ${ }^{176} \mathrm{Lu}$ on $\left.{ }^{176} \mathrm{Hf}\right)$. Instrumental mass bias for $\mathrm{Yb}$ isotopes (calculation of $\beta^{\mathrm{Yb}}$ ) was monitored for each measurement using an exponential law, and 
corrected to the natural ratio ${ }^{172} \mathrm{Yb} /{ }^{173} \mathrm{Yb}=1.35351$. Mass fractionation of $\mathrm{Lu}$ isotopes was assumed identical to that of $\mathrm{Yb}$ isotopes $\left(\beta^{\mathrm{Lu}}=\beta^{\mathrm{Yb}}\right)$. The isobaric interferences were subsequently corrected to mass bias-corrected ${ }^{176} \mathrm{Yb} /{ }^{173} \mathrm{Yb}=0.79502$ and ${ }^{176} \mathrm{Lu} /{ }^{175} \mathrm{Lu}=0.02656$ (see Gerdes and Zeh (2006)). Mass bias for $\mathrm{Hf}$ isotopes $\left(\beta^{\mathrm{Hf}}\right)$ was determined using an exponential law and normalized to ${ }^{179} \mathrm{Hf} /{ }^{177} \mathrm{Hf}=0.7325$. Accuracy and external reproducibility of the method were controlled by repeated analyses of reference zircon standards GJ-1 (Jackson et al., 2004; Morel et al., 2008), Plešovice (Sláma et al., 2008), and Temora (Woodhead et al., 2004) (see Table S7 for results on the standards). The quoted uncertainties on ${ }^{176} \mathrm{Hf} /{ }^{177} \mathrm{Hf}$ ratios and $\varepsilon \mathrm{Hf}(\mathrm{t})$ are quadratic additions of within-run precision of each measurement with the external reproducibility (2 S.D.) of the reference zircon standard GJ-1 ( $\sim 70 \mathrm{ppm}$, see data table). Data reduction was carried out using an in-house MS Excel(C) spreadsheet (Gerdes and Zeh, 2006; 2009).

Calculation of initial ${ }^{176} \mathrm{Hf} /{ }^{177} \mathrm{Hf}$ ratios were performed using the individual ${ }^{176} \mathrm{Lu} /{ }^{177} \mathrm{Hf}$ ratio of each measurement, a decay constant of $\lambda^{176} \mathrm{Lu}=1.867 \times 10^{-11}$ (Scherer et al., 2001; Söderlund et al., 2004) and the emplacement age obtained by $\mathrm{U}-\mathrm{Pb}$ zircon dating. For the calculation of the $\varepsilon \mathrm{Hf}(\mathrm{t})$, parameters of the chondritic uniform reservoir (CHUR) recommended by Bouvier et al. (2008) were used $\left({ }^{176} \mathrm{Lu} /{ }^{177} \mathrm{Hf}=0.0336 ;{ }^{176} \mathrm{Hf} /{ }^{177} \mathrm{Hf}=0.282785\right)$. Two-step depleted mantle (DM) Hf model ages $\left(\mathrm{T}_{\mathrm{DM} 2}{ }^{\mathrm{C}}\right)$ were calculated using a DM model considering linear regression from present-day depleted mantle as recommended by Griffin et al. (2002), i.e. ${ }^{176} \mathrm{Lu} /{ }^{177} \mathrm{Hf}=0.0384$ and ${ }^{176} \mathrm{Hf} /{ }^{177} \mathrm{Hf}=0.28325$, and an average ${ }^{176} \mathrm{Lu} /{ }^{177} \mathrm{Hf}$ of 0.0113 for the crustal reservoir.

\section{Results}

\subsection{Geochemistry}

Regardless of the rock type, samples from the VOF are all very silicic $\left(\mathrm{SiO}_{2}>68 \mathrm{wt} . \%\right)$ and have a granitic (s.s.) composition (Fig. 6a). More specifically, they show high A/CNK (1.05 to 1.4) and A/NK (1.1 to 1.6) implying that their protoliths are peraluminous granites (Fig 6b). The very high values displayed by some samples (A/CNK in the range 1.4 to 1.8$)$ probably reflect alkali losses during amphibolite-facies metamorphism (not identified by the abovementioned filtering procedure, see section 3.1). Mg\# is highly scattered (2 to 60, Fig. 6c). Leucogneiss are $\mathrm{SiO}_{2}$ richer (> 74 wt. $\%)$ and have lower and variable $\mathrm{Mg} \#(<30)$ compared to augen gneisses $\left(\mathrm{SiO}_{2}=69-75\right.$ wt.\%; $\mathrm{Mg} \#=30-55)$. Banded gneisses span in composition between those two endmembers. As 
a whole, VOF compositions remarkably mimic that of Variscan S-type granites from the eastern Massif Central (Fig. 6a,b,c). We investigated possible systematic differences between the three domains (Pilat, Arc-de-Fix and Vivarais) of the VOF. We used linear discrimination analysis (LDA) on major elements, a statistical tool calculating the linear combination of variables that maximizes the difference between three previously defined sets of data (Fig. 6d). LDA was computed using the open-source R language (Ihaka and Gentleman, 1996) and the package MASS (Venables and Ripley, 2002). We followed the method of Aitchison (1986) and implemented the compositional variables $\mathrm{X}\left(\mathrm{Al}_{2} \mathrm{O}_{3}, \mathrm{MgO}, \mathrm{FeO}_{\mathrm{t}}, \mathrm{TiO}_{2}, \mathrm{CaO}, \mathrm{Na}_{2} \mathrm{O}, \mathrm{K}_{2} \mathrm{O}\right)$ as $\log \left(\mathrm{X} / \mathrm{SiO}_{2}\right)$ ratios. No systematic difference is observed and samples from all three regions have statistically similar major elements compositions.

Like for major oxides, trace element compositions of VOF samples are very homogeneous between the three domains (Fig. 7). Augen gneisses show a slight enrichment in Light Rare Earth Elements (La/Yb: mostly 6-14), flat Heavy Rare Earth Elements patterns (Dy/Yb: 1.3-3) together with a negative Eu anomaly (Fig. 7a). Leucogneisses are less enriched in LREE (La/Yb: mostly 2-6), have similar HREE patterns and a more pronounced Eu anomaly (Fig. 7a). Banded gneisses seem significantly depleted in HREE compared to the other lithologies (La/Yb: 25 to 50), but this difference may not be statistically significant given that trace elements are only available for two samples. All rock types have multi-element patterns characterized by significant negative $\mathrm{Ba}-\mathrm{Sr}$, $\mathrm{Nb}-\mathrm{Ta}$ and $\mathrm{Ti}$ anomalies and positive $\mathrm{Pb}$ and $\mathrm{U}$ anomalies (Fig. 7b). As a whole leucogneisses are depleted in all incompatible elements compared to augen gneisses with the exception of $\mathrm{Nb}-\mathrm{Ta}$ (constant) and $\mathrm{Rb}-\mathrm{U}$ (enriched in the leucogneisses).

\section{2 $\mathrm{U}-\mathrm{Pb}$ dating}

\subsubsection{Zircon textures}

Figure 5 shows representative CL images of zircon crystals from the investigated VOF samples. Zircon grains are idiomorphic to sub-idiomorphic, display aspect ratios between 1.5 and 3.5 and show well-developed pyramidal tips (Fig. 5a,b). Grains range in size from 200 to $350 \mu \mathrm{m}$ in augen

gneisses and are notably smaller in leucogneisses $(150-250 \mu \mathrm{m})$. Core-rim relationships are commonly observed (Fig. 5). They often consist of CL-dark or bright sub-idiomorphic to rounded cores, mantled by a rim showing typical oscillatory zoning. A careful examination of CL images reveals the existence of small textural discontinuities in such oscillatory zoning, with truncations 
and irregular surfaces being common. Finally, few grains display very CL-bright narrow $(<10 \mu \mathrm{m})$ rims (see Fig. 5d).

\subsubsection{Sample MM06}

This sample is a typical « Arc-de-Fix » augen gneiss collected from the cliff along the RD40 road below the village of St-Privat-d'Allier (Fig. 2 and 4a). Twenty-six analyses were performed on 24 zircon grains. Three cores yield concordant Neoproterozoic ${ }^{238} \mathrm{U} /{ }^{206} \mathrm{~Pb}$ dates at $559.7 \pm 13.4,660.3$ \pm 15.2 and $721.4 \pm 16.9$ Ma respectively (errors quoted at $2 \sigma$, Table S5). Plotted in the TeraWasserburg diagram, 21 analyses from rims or grains devoid of any core trend along a mixing line between radiogenic and common $\mathrm{Pb}$ compositions. This trend has a lower intercept at $540.5 \pm 3.2$ $\mathrm{Ma}(\mathrm{MSWD}=0.26)$ and an identical Concordia date of $541.8 \pm 3.1 \mathrm{Ma}\left(\mathrm{MSWD}_{\mathrm{C}+\mathrm{E}}=0.34\right.$, Fig. $8 \mathrm{a})$ is calculated out of the 16 statistically equivalent concordant analyses. Two spots (z10 and z20) have ${ }^{206} \mathrm{~Pb} /{ }^{238} \mathrm{U}$ dates of $c .510 \mathrm{Ma}$ that are statistically different from those of the main population, and were therefore not included in the calculation. There is no systematic relationship between ${ }^{238} \mathrm{U} /{ }^{206} \mathrm{~Pb}$ dates and $\mathrm{Th} / \mathrm{U}$ ratios which range between 0.02 and 0.64 . This observation is also valid for the three other samples.

\subsubsection{Sample MM11}

Sample MM11 is an augen gneiss collected at the "Col de Meyrand" (Fig. 4a). Out of 28 analyses, 7 correspond to zircon cores. Five yielded concordant Neoproterozoic ${ }^{206} \mathrm{~Pb} /{ }^{238} \mathrm{U}$ dates ranging from $580.7 \pm 14.1 \mathrm{Ma}(\mathrm{z} 30)$ to $1077.1 \pm 25.0 \mathrm{Ma}(\mathrm{z} 33)$ and two discordant ${ }^{207} \mathrm{~Pb} /{ }^{206} \mathrm{~Pb}$ dates of 860 Ma and $2100 \mathrm{Ma}$ (Fig. 8b). In the Tera-Wasserburg diagram, a total of 18 spots from zircon rims and core-free grains define a trend with a lower intercept at 541.2 $\pm 3.6 \mathrm{Ma}(\mathrm{MSWD}=0.34)$, which slope is mostly controlled by discordant spot z38. Excluding the latter and the slightly discordant spot z44, an identical Concordia date of $542.5 \pm 3.1 \mathrm{Ma}\left(\operatorname{MSWD}_{\mathrm{C}+\mathrm{E}}=0.43\right.$, Fig. $\left.8 \mathrm{~b}\right)$ can be

calculated out of 16 analyses. Three spots yielded significantly younger ${ }^{206} \mathrm{~Pb} /{ }^{238} \mathrm{U}$ dates (two are discordant and one concordant with $\mathrm{a}{ }^{206} \mathrm{~Pb} /{ }^{238} \mathrm{U}$ date of $502.6 \pm 12.1 \mathrm{Ma}$ ) that were thus not included in the calculations.

\subsubsection{Sample MM10}

MM10 is a leucogneiss collected at the Pont-du-Bon-Dieu along the RD6 road south of LabastidePuylaurent. It features an intricate association with mylonitic augen gneiss (see Fig. 4d). Sixty-five 
analyses were performed, out of which 12 spots on zircon cores gave concordant Neoproterozoic ${ }^{206} \mathrm{~Pb} /{ }^{238} \mathrm{U}$ dates ranging from $560.3 \pm 13.2 \mathrm{Ma}(\mathrm{z} 88)$ to $657.8 \pm 14.5 \mathrm{Ma}(\mathrm{z} 136)$ and $805.8 \pm 17.5$ Ma (z137) to $921.7 \pm 20.6 \mathrm{Ma}(z 130$, Table S5). Three discordant analyses, also from zircon cores, yielded older Paleoproterozoic ${ }^{207} \mathrm{~Pb} /{ }^{206} \mathrm{~Pb}$ dates of 1600,1900 and $2400 \mathrm{Ma}$. Twenty-eight spots from zircon rims or grains without cores trend along a mixing line between radiogenic and common $\mathrm{Pb}$ with a lower intercept at $540.7 \pm 2.7 \mathrm{Ma}(\mathrm{MSWD}=0.11)$. Considering the concordant analyses only $(\mathrm{n}=26)$, a Concordia date of $541.4 \pm 2.3 \mathrm{Ma}\left(\mathrm{MSWD}_{\mathrm{C}+\mathrm{E}}=0.38\right.$, Fig. $\left.8 \mathrm{c}\right)$ can be calculated. Thirteen concordant spots have ${ }^{206} \mathrm{~Pb} /{ }^{238} \mathrm{U}$ dates ranging between $523.4 \pm 11.1 \mathrm{Ma}$ and $482.4 \pm$ 11.1 Ma. Those were not included in the calculations because as argued below (see section 5.1), they would correspond to radiogenic $\mathrm{Pb}$ loss from the main population at ca. $541 \mathrm{Ma}$.

\subsubsection{Sample MM09}

Sample MM09 is a leucogneiss boudin stretched within an augen gneiss matrix and exposed along the D906 road south of Langogne (Fig. 4b). Out of 25 analyses, 3 correspond to zircon cores: one displays a concordant ${ }^{206} \mathrm{~Pb} /{ }^{238} \mathrm{U}$ date of $686.7 \pm 16.3 \mathrm{Ma}$ and two show similar discordant Paleoproterozoic ${ }^{207} \mathrm{~Pb} /{ }^{206} \mathrm{~Pb}$ dates of $1700 \mathrm{Ma}$ (Table S5). From the remaining data obtained on rims and core-free zircons, nine concordant spots define a Concordia date of $545.9 \pm 4.3 \mathrm{Ma}$ $\left(\mathrm{MSWD}_{\mathrm{C}+\mathrm{E}}=1.05\right.$, Fig. $\left.8 \mathrm{~d}\right)$; the rest of the data show younger ${ }^{206} \mathrm{~Pb} /{ }^{238} \mathrm{U}$ dates and are notably discordant, with the exception of two concordant spots having ${ }^{206} \mathrm{~Pb} /{ }^{238} \mathrm{U}$ dates of $509.9 \pm 12.2 \mathrm{Ma}$ and $516.7 \pm 12.4$ Ma respectively.

\subsection{Lu - Hf isotope data}

Zircon Lu-Hf analyses obtained for augen gneisses MM06 and MM11 are displayed in Table S6. Only magmatic zircon grains and rims were analyzed. Therefore, initial Hf isotope compositions were calculated using the intrusion age determined for each sample (see section 4.2). The ${ }^{176} \mathrm{Hf} /{ }^{177} \mathrm{Hf}(\mathrm{t})$ ratios of magmatic zircons from augen gneiss MM06 range from $0.282376 \pm$ 0.000023 to $0.282487 \pm 0.000036$ ( 2 S.E. - standard error), corresponding to $\varepsilon \mathrm{Hf}(\mathrm{t})$ of -2.4 to 1.6 with a chondritic average value of $-0.2 \pm 2.9$ (2 S.D. - standard deviation; Fig. 9a and Table 1). Augen gneiss sample MM11 shows a tighter range of zircon ${ }^{176} \mathrm{Hf} /{ }^{177} \mathrm{Hf}(\mathrm{t})$, from $0.282407 \pm$ 0.000027 to $0.282462 \pm 0.000025$ ( 2 S.E. - standard error) equivalent to $\varepsilon H f(t)$ of -1.3 to 0.7 (Fig. 9a) and yielding an identical average $\varepsilon \mathrm{Hf}(\mathrm{t})$ at $-0.2 \pm 1.2$ (2 S.D. - standard deviation; Table 1). 


\section{Discussion}

5.1 Interpretation of the $\mathrm{U}-\mathrm{Pb}$ data and orthogneisses emplacement ages

All investigated samples are characterized by a largely dominant population of zircon grains having statistically equivalent and concordant ${ }^{206} \mathrm{~Pb} /{ }^{238} \mathrm{U}$ dates between $550-540 \mathrm{Ma}$, which we interpret as the crystallization ages of the VOF granitic protoliths. This interpretation is supported by (i) the fact that these data were obtained on zircon rims or grains devoid of any core; (ii) the typical magmatic oscillatory zoning showed by the analyzed domains (Fig. 7); and (iii) the well-developed $\{211\}$ pyramids of these crystals, which are characteristic of zircon grown in peraluminous granitic magmas (Pupin, 1980; Belousova et al., 2006), in line with whole-rock geochemistry of the investigated samples (Fig. 5b).

From this perspective, we interpret the 28 analyses obtained from zircon cores, showing notably older ${ }^{238} \mathrm{U} /{ }^{206} \mathrm{~Pb}$ dates (from $560 \mathrm{Ma}$ up to $1100 \mathrm{Ma}, 75 \%$ of which being $>95 \%$ concordant), as reflecting zircon inheritance from the source of these (meta)granites or xenocrysts sampled from the country-rocks during magma ascent and emplacement. The presence of these inherited cores and xenocrysts is significant because they occur in all of the four investigated samples (Fig. 8) and represent a non-negligible proportion of the dataset (ca. 19\%). In addition, CL images hint the presence of more small, strongly resorbed or irregular cores (see Fig. 7c close to z134 or 7d close to z78) that could not be analyzed by LA-ICP-MS.

A significant amount of zircon analyses (including 17 concordant ones) show ${ }^{206} \mathrm{~Pb} /{ }^{238} \mathrm{U}$ dates younger than the 550-540 Ma crystallization age, in the range 523 to $482 \mathrm{Ma}$. These are well represented in the leucogneiss samples (Fig. 8), particularly MM10 (Fig. 8c). We argue that these dates do not correspond to any geological event but rather result from radiogenic $\mathrm{Pb}$ loss affecting the main, 545-540 Ma-old zircon population. Firstly, these dates are often associated with incoherent core-rim relationships (cores having younger ${ }^{238} \mathrm{U} /{ }^{206} \mathrm{~Pb}$ dates than their associated rims, see for instance zircons 93, 103 and 106, Fig. 7c). Second, recent $\mathrm{Pb}$ loss is represented by horizontal lines in the Tera-Wasserburg diagram because it does not affect ${ }^{207} \mathrm{~Pb} /{ }^{206} \mathrm{~Pb}$ ratios (Fig. 8c). The weak curvature of the Concordia at Paleozoic times implies that the Discordia and Concordia curves are nearly parallel so that any c. 540 Ma-old zircon having experienced a limited $\mathrm{Pb}$ loss would still be sub-concordant within uncertainty. 
Following the abovementioned interpretations, the igneous protoliths of all the investigated VOF samples show overlapping emplacement ages of c. $542 \mathrm{Ma}$, at the Ediacaran/Cambrian boundary (541 \pm 1 Ma, Finney et al. (2013)). This age is close to, yet significantly older than the Cambrian $\mathrm{Rb} / \mathrm{Sr}$ date of $528 \pm 9$ Ma obtained by R'Kha Chaham et al. (1990) on Arc de Fix augen gneisses. It complies with the zircon $\mathrm{Pb}$ evaporation age of $533 \pm 22 \mathrm{Ma}$ (Mougeot et al., 1997) and the chemical U-Th- $\mathrm{Pb}$ monazite date of $543 \pm 25 \mathrm{Ma}$ (Be Mezeme et al., 2006) both obtained on unmolten to anatectic Arc de Fix augen gneisses. It is also identical to the whole-rock $\mathrm{Rb}-\mathrm{Sr}$ age of $545 \pm 14$ Ma determined by Caen-Vachette (1979) for the Pilat leucogneisses.

\subsection{Petrogenesis of the magmatic suite}

The VOF samples display remarkable geochemical homogeneity, regardless of their geographic provenance. Their composition is consistent with the chemistry of peraluminous S-type granites (see Fig. 6). Moreover, zircon grains from augen- and leucogneisses have similar, low aspect ratios which comply with a plutonic origin for the protoliths of both rocks (Corfu et al., 2003), and morphologies typical of crystals formed in S-type granitic magmas (Pupin, 1980; Belousova et al., 2006) (Fig. 5). Furthermore, the obtained emplacement ages for the four samples (545-540 Ma) are overlapping within analytical uncertainties. All these lines of evidence indicate that the VOF represent a former, large S-type granitic batholith emplaced at the Ediacaran/Cambrian boundary that was subsequently deformed and dismembered by Variscan tectonics. The aim of this section is to characterize its petrogenesis.

Given the narrow range of silica contents (mostly 70-76 wt.\%) and the apparent similar chemical composition of investigated samples, we plotted the geochemical data using the principal component approach. This procedure helps pinpointing petrogenetic trends (Buccianti and Peccerillo, 1999; Janoušek et al., 2004). Principal components were calculated using the internal routine of the GCDkit software (Janoušek et al., 2006) after recasting the chemical compositions to $100 \%$ in the system $\mathrm{SiO}_{2}-\mathrm{Al}_{2} \mathrm{O}_{3}-\mathrm{MgO}-\mathrm{FeO}-\mathrm{TiO}_{2}-\mathrm{CaO}-\mathrm{Na}_{2} \mathrm{O}-\mathrm{K}_{2} \mathrm{O}$. The first three principal components account for $86 \%$ of the cumulative variance of the system. As principal component 1 (P.Comp ${ }_{1}$ ) mostly opposes silica vs. compatible elements contents $\left(\mathrm{MgO}, \mathrm{FeO}, \mathrm{TiO}_{2}, \mathrm{CaO}\right)$, the most silicic rocks (i.e., the leucogneisses) feature high P.Comp ${ }_{1}$ values (Fig. 10). Similar to trends observed in major elements diagrams, the banded gneisses' compositions spread between an augen gneiss and a leucogneiss endmember. 


\subsubsection{Source of the magmatic suite}

The complete absence of mafic or even intermediate meta-igneous rocks in the VOF together with the observation of inherited zircon cores in the dated samples precludes the formation of the magmatic suite by fractionation of mantle-derived magmas. This absence rather suggests that the granitic magmas originated from melting of pre-existing crustal lithologies. The low $\mathrm{CaO}$ contents (0.2-1.5 wt.\%) displayed by samples from the VOF discard amphibole-rich mafic rocks as a potential source material (Coldwell et al., 2011; Sisson et al., 2004), such that meta-sediments and meta-intermediate to felsic igneous rocks are most adequate as potential sources.

Figure 11 compares the composition of VOF samples to primary liquids formed by melting of a range of meta-sedimentary and meta-igneous crustal lithologies. Relevant melting conditions correspond to a range of crustal pressures from 3 to $15 \mathrm{kbar}$ and temperatures $<900^{\circ} \mathrm{C}$ in agreement with (i) the absence of magmatic orthopyroxene in the investigated suite (Frost and Frost, 2008); (ii) first-order estimates given by zircon saturation thermometry, the persistence of inherited zircon cores in the dated samples indicating maximum magma temperatures of $780 \pm 15^{\circ} \mathrm{C}$ upon emplacement (calculated with the equation of Boehnke et al. (2013)) and therefore, melting temperatures that cannot have been in excess of $840-885^{\circ} \mathrm{C}$ considering a maximum melting pressure of $15 \mathrm{kbar}$ and reasonable adiabats (i.e. between 4 and $7^{\circ} \mathrm{C} / \mathrm{kbar}$; Annen et al., 2006; Clemens et al. 1997; Holtz and Johannes, 1994). Experimental melt compositions are projected on the principal component framework determined from statistical analysis of the VOF samples (Fig. 10). The considered experimental studies together with respective starting materials and $\mathrm{P}-\mathrm{T}$ conditions are summarized in Table 2.

Clearly, tonalites and metaluminous granodiorites are inappropriate source rocks because melts derived from those lithologies have respectively lower Mg\# (Fig. 11f) and/or lower $\mathrm{K}_{2} \mathrm{O} / \mathrm{Na}_{2} \mathrm{O}$ (Fig. 11h) than natural samples. Peraluminous granodiorite melts display more adequate compositions but can only account for a small part of the natural samples variability centered on P.Comp $1 \sim 0$ (Fig. 11). By contrast, melting of quartz-rich to quartz-poor pelites, greywackes and volcanoclastic rocks generates a range of primary melt compositions that fairly reproduce the compositional scatter of the augen- and part of the banded gneisses, i.e. samples with $-4<$ P.Comp 1 $<0.5$. This is in line with the VOF samples displaying a geochemical affinity to S-type granites (see Fig. 6) that derive from melting of such lithologies (Chappell and White, 2001). Therefore, it 
is reasonable to consider that the granitic protoliths of augen- and banded gneisses from the VOF represent liquids which originated from melting of a heterogeneous sedimentary sequence at 750 $<\mathrm{T}<900^{\circ} \mathrm{C}$ and $3<\mathrm{P}<15 \mathrm{kbars}$. This is consistent with the wide range of inherited zircon ages, scattering from 560 to $1100 \mathrm{Ma}$ (Fig. 8), which points to an Ediacaran depositional age for the source sediments.

Importantly, leucogneiss samples (with P.Comp $1>0.5$ ) clearly differ from any investigated experimental melt composition. Two non-exclusive scenarios may account for their origin: (i) leucogneisses derive from source materials and/or at $\mathrm{P}-\mathrm{T}$ conditions not represented in our database; or (ii) they result from fractionation of the granitic magmas at the origin of augen- and banded gneisses with P.Comp $1<0.5$. The first hypothesis is unlikely, since the range of investigated source materials (Table 2) is fairly representative of the most common felsic sources in the crust, and the investigated temperature range $\left(680-900^{\circ} \mathrm{C}\right)$ encompasses a wide domain of melting conditions, from water-present melting $\left(\right.$ c. $\left.650-700^{\circ} \mathrm{C}\right)$ to muscovite dehydration melting (c. 720 $750^{\circ} \mathrm{C}$ ) and biotite dehydration melting $\left(\right.$ c. $\left.850-875^{\circ} \mathrm{C}\right)$. The feasibility of the fractionation hypothesis is tested hereafter.

\subsubsection{Leucogneiss petrogenesis}

In this section, we investigate whether leucogneisses could be derived from fractionation of the magma at the origin of the augen gneisses. Figures $12 \mathrm{a}$ and $\mathrm{b}$ depict the chemical evolution of $\mathrm{a}$ magma fractionating minerals typically found in peraluminous S-type granites: K-feldspar, oligoclase, biotite, muscovite, cordierite, garnet (Bea et al., 1994; Tartèse and Boulvais, 2010). Fractionation vectors are calculated using mass balance for major elements, and Rayleigh-type fractionation together with partition coefficients for traces (cordierite could not be modelled for traces due to the lack of available partitioning data). In terms of major elements, fractionation of an augen gneiss-like liquid to a leucogneiss composition cannot be driven by muscovite, nor Kfeldspar, as both result in too high values for PComp.3 (Fig. 12b). Leucogneisses are better reproduced by concomitant fractionation of plagioclase and a ferromagnesian phase (biotite, garnet and/or cordierite, Fig. 12a,b). The low Ba-Sr contents displayed by leucogneisses can result from fractionation of either a K-feldspar dominated assemblage (however, this is ruled out by major elements), or a polymineralic assemblage comprising $40 \%$ biotite and $60 \%$ plagioclase (Fig. 12c). Fractionation of plagioclase is also in agreement with the more pronounced Eu anomaly displayed 
by leucogneisses (Fig. 6). The decrease in HREE and $\mathrm{Y}$ contents from augen gneisses to leucogneisses could result from fractionation of a small amount of garnet, zircon or xenotime (Bea, 1996). The same observation for LREE could originate from minor fractionation of apatite and/or monazite (Bea, 1996). As a result, fractionation of a Pl+Bt (+accessory phases) assemblage from an augen gneiss-like magma satisfactorily accounts for the composition of leucogneisses.

\subsubsection{Emplacement depth}

Leucogneisses are highly silicic $\left(\mathrm{SiO}_{2}\right.$ generally ranging between 74 and $\left.77 \mathrm{wt} . \%\right)$, mostly contain quartz+feldspar, and, as demonstrated above, correspond to residual melts after fractionation of a $\mathrm{Pl}+\mathrm{Bt}$ assemblage out of a melt similar to augen gneisses. Therefore, the leucogneisses compositions should be very close to that of the minimum or eutectic in the haplogranitic system. The position of this minimum/eutectic in the ternary Qz-Ab-Or diagram is a function of the water activity and the pressure of crystallization (Johannes and Holtz, 1996). At a given pressure, decreasing water activity (corresponding to $\mathrm{H}_{2} \mathrm{O}$-undersaturated melts) shifts the position of the minimum/eutectic towards the Qz-Or join keeping the normative Qz proportion constant (Johannes and Holtz, 1996). The latter is therefore strictly pressure-dependent and is an indicator of the pressure of magma crystallization. In this section, we aim at retrieving the depth of emplacement/crystallization of the batholith by comparing the compositions of leucogneisses to that of the haplogranitic minimum/eutectic as predicted by experimental data.

Experimental data on the Qz-Ab-Or- $\mathrm{H}_{2} \mathrm{O}$ system have been compiled by Blundy and Cashman (2001). We projected natural leucogneiss compositions following the recommendations of the same authors by: (i) calculating the CIPW norm; (ii) correcting the effect of the An normative component on the position of the natural melt in the ternary diagram. Only samples with measured $\mathrm{Fe}_{2} \mathrm{O}_{3} / \mathrm{FeO}$ ratios were retained (total of 66 analyses) to ensure calculation of accurate normative values. Leucogneisses from the VOF cluster around the minimal melt compositions expected at pressures of $0.5-2$ kbars and water-saturated conditions $\left(a_{\mathrm{H} 2 \mathrm{O}}=1\right.$, Fig. 13). Few samples show higher Qz modal values which could result from limited sub-solidus chemical modifications or the presence of quartz veinlets.

Since leucogneisses and augen gneisses are intimately associated in the field (see section 2.2), a pressure of crystallization for the whole batholith of $0.5-2 \mathrm{kbars}$ can be inferred. This corresponds 
to depths of $\sim 2$ to $7 \mathrm{~km}$ and suggests that the VOF S-type granites emplaced at shallow crustal levels.

\subsection{Interpretation of $\mathrm{Lu}-\mathrm{Hf}$ data}

The $\varepsilon \mathrm{Hf}(\mathrm{t})$ variability within a given sample is small ( $<4$ and even $<2 \varepsilon H f-u n i t s$ in MM11) and of the same order of magnitude than the analytical uncertainties (i.e. $\pm 1.1 \varepsilon H f-u n i t s)$, indicating that zircons crystallized from a magma with relatively homogeneous Hf isotope composition. Both samples reveal identical average $\varepsilon \mathrm{Hf}(\mathrm{t})$ clustering around the chondritic value, taken as representative of that of the magma at the time of crystallization.

Clearly, a chondritic mantle source for the magmas at the origin of the VOF must be discarded because geochemical data are rather in line with a sedimentary source (see section 5.2.1). Accordingly, the chondritic value could originate from the melting of an isotopically homogeneous sedimentary reservoir that would itself rework continental crust extracted from the Depleted Mantle $(\mathrm{DM})$ at $\sim 1.3 \mathrm{Ga}$ (calculated model age with a crustal ${ }^{176} \mathrm{Lu} /{ }^{177} \mathrm{Hf}$ of 0.0113 , from Taylor and McLennan (1985)). However, there is no crust of that specific age in the north Gondwana margin, where crust production occurred in the Archean (2.5-3.3Ga), Paleoproterozoic (1.8-2.2Ga) and Neoproterozoic (0.6-0.7Ga) (Gerdes and Zeh, 2006; Linnemann et al., 2014; Nance et al., 1991). As a result, the chondritic signature of the VOF parental magmas most probably stems results from the melting of a sedimentary source composed of a mixture of the three above-mentioned reservoirs, including at least $50 \%$ of Neoproterozoic juvenile crust (as proposed for Variscan Stype granites from the same area (Moyen et al., 2017; Turpin et al., 1990)). Ediacaran metasediments throughout the Variscan belt of Western Europe are characterized by a very large spread of detrital zircon $\varepsilon \mathrm{Hf}(\mathrm{t})$, specifically ranging from $c$. +10 down to $c$. -40 at $600 \mathrm{Ma}$ (Fig. $9 b$ ), interpreted as reflecting the contribution of terrigenous material from both juvenile Neoproterozoic crust (such as the Arabian-Nubian Shield) and ancient, Paleoproterozoic to Archean crust from Gondwana (Chelle-Michou et al., 2017; Linnemann et al., 2014; Orejana et al., 2015). Therefore, the Ediacaran metasediments represent adequate sources for the VOF granites. The U-Pb dates of inherited zircons in the VOF samples strongly support this interpretation, since those are dominantly in the range 560-900 Ma (20 analyses out of 28 , i.e. $71 \%$ ) that is typical for detrital zircons in Ediacarian metasediments of the northern Gondwana margin (Chelle-Michou et al., 2017; Linnemann et al., 2014; Orejana et al., 2015; Teixeira et al., 2011; see also Fig. 8). 
The Hf isotope homogeneity displayed by the parental magmas of the VOF (Fig. 9b) is rather uncommon for S-type granites, which magmatic zircons commonly show larger variations of $\varepsilon H f(t)$, most often of $\sim 10$ epsilon-units (Appleby et al., 2009; Farina et al., 2014; Teixeira et al., 2011; Villaros et al., 2012). Based on the natural case of the Cape Granite Suite in South Africa, Villaros et al. (2012) proposed that the Hf isotope scatter observed in S-type granites results from the dissolution at emplacement level of inherited detrital zircons in the melt phase. Such grains being isotopically disparate, their dissolution creates small-scale $\mathrm{Hf}$ isotopic heterogeneities captured by newly formed zircon when the melt crystallizes. However, Farina et al. (2014) showed that the cooling history of the magmatic body exerts a strong control on this process, with fast cooling rates $\left(\geq 0.0125{ }^{\circ} \mathrm{C} / \mathrm{yr}\right)$ leading to rapid zircon saturation. In that case, especially if some zircon has already been dissolved during melting and/or transport and the Hf isotopic composition was homogenized thereby, igneous zircons crystallized at the emplacement level would not show strong $\mathrm{Hf}$ isotope heterogeneities (i.e. about 1 \&Hf unit even though the initial inherited zircons showed compositional variation in excess of $10 \mathrm{eHf}$ units; Farina et al., 2014). It is therefore likely that the parental magmas of the VOF experienced such a process, i.e. (i) inherited zircon dissolution during melting and/or ascent in the crust; (ii) coeval homogenization of Hf isotopic compositions in the melt; and (iii) subsequently, limited further dissolution at the emplacement level (if any).

Liquids formed by melting of sedimentary lithologies at $750-850^{\circ} \mathrm{C}$ can dissolve up to $115-390$ ppm $\mathrm{Zr}$ (calculated using the equation of Boehnke et al., 2013 and the composition of experimental melts from the compilation presented in Table 2), which corresponds to 14 to $48 \%$ dissolution of detrital zircons present in the sedimentary source lithology, assuming a source composition of ca. $200 \mathrm{ppm} \mathrm{Zr}$ (close to the average composition of the upper crust, Rudnick and Gao, 2003), that all $\mathrm{Zr}$ is hosted in detrital zircons and an average melt fraction of ca. 25\% (derived from experimental data listed in Table 2). Consistently, $\mathrm{Zr}$ concentrations in augen and banded gneisses from the VOF range mostly from ca. 50 to $180 \mathrm{ppm}$, indicating that they would have left the source in a $\mathrm{Zr}$ undersaturated state after dissolution of maximum 6-23\% detrital zircon (and probably much less, given the presence of inherited zircons in the VOF samples) using the same parameters as above. Close to their liquidus, the resulting melts would have readily undergone homogenization through advection and elemental/ isotopic diffusion. Conversely, zircon saturation temperatures of the VOF samples are around $780^{\circ} \mathrm{C}$ (see section 5.2.1), meaning that they would have very rapidly reached saturation upon emplacement and cooling, especially considering that they emplaced at relatively 
shallow crustal levels ( $\leq 7 \mathrm{~km}$, see section 5.2.3). This would have indeed promoted fast cooling rates and in turn, limited dissolution (if any) of the remaining inherited zircon cores (Farina et al., 2014). All lines of evidence therefore suggest that the unusually homogeneous zircon Hf isotopic composition of the S-type VOF granites result from a combination of Zr-undersaturated conditions during melting and transport in the crust followed by early saturation upon emplacement owing to rapid cooling at shallow crustal levels.

\subsection{Geodynamic setting of late Ediacaran magmatism in the French Massif Central}

A compilation of available geochronological data ( $\mathrm{n}=74$ dated samples) shows that pre-Variscan magmatism in the French Massif Central spanned over $150 \mathrm{Ma}$ from the Ediacaran (c. $600 \mathrm{Ma}$ ) to the late Ordovician (c. $450 \mathrm{Ma}$ ) and possibly the Early Silurian (Fig. 14). The age pattern shows a bimodal distribution reflecting the existence of two pulses of magmatic activity at c. $475 \mathrm{Ma}$ (Ordovician) and c. $540 \mathrm{Ma}$ (Ediacaran/Cambrian boundary). As outlined before, Ordovician magmatic activity in the FMC is interpreted as reflecting long-lived extension of the Northern Gondwana margin that culminated in rifting and the opening of small-scale oceanic basins (Lardeaux et al., 2014). However, at the scale of the Variscan belt, the significance of this Ordovician event is much discussed and contrasted geodynamic settings have been proposed such as an active margin environment with a fore-arc accretionary complex (Zurbriggen, 2015) and continental subduction (Villaseca et al., 2016).

The existence of the Ediacaran/Cambrian peak together with its origin and significance have not been addressed in the FMC. By that time, the crust segment today exposed in the FMC was located along the northern margin of Gondwana (Stampfli et al., 2013) and was therefore likely affected by the Cadomian orogeny, a Cryogenian-Ediacaran Western Pacific-type marginal orogenic system (Nance et al., 1991). Accordingly, remnants of Cadomian granitoid rocks have been described in several parts of the Variscan belt (see review in Garfunkel (2015)). In the following, we compare the Cadomian magmatic record of the eastern FMC to that of the closest crustal block shaped by the Cadomian orogeny but nearly devoid of Variscan imprint: the Mancellian Domain of the North Armorican Massif (Fig. 1). Today located $500 \mathrm{~km}$ NW of the Velay Dome, it preserves an excellent record of the Cadomian orogenic evolution (Ballèvre et al., 2001; Chantraine et al., 2001) and the developed comparison would better constrain the origin and geodynamic setting of late Ediacaran magmatism in the FMC. 
The Mancellian Domain comprises two main lithological units: (i) a terrigenous sedimentary sequence of Ediacaran ("Brioverian") age, interpreted as a turbidite-type back-arc to retro-arc basin (Ballèvre et al., 2001; Linnemann et al., 2014); (ii) a range of granitoids which intrude the sediments and develop thermal aureoles that suggest emplacement depths lower than $6 \mathrm{~km}$ (Ballèvre et al., 2001). Available ages on this magmatism range between 550 and $540 \mathrm{Ma}$ (Egal et al., 1996; Egal et al., 2011; Peucat, 1986). This configuration clearly resembles that observed in the LGU of the eastern FMC (Ledru et al., 2001). As demonstrated above, orthogneisses correspond to a late Ediacaran S-type granitic suite emplaced at shallow crustal levels $(2-7 \mathrm{~km})$. Field observations clearly indicate that the VOF is intrusive within the regional paragneisses (Ledru et al., 1994). Consequently, our dating results on the VOF importantly constrain a minimum deposition age of $545 \mathrm{Ma}$ for the sedimentary protoliths of the paragneisses, besides consistent with constraints based on the age of the youngest detrital zircons in these rocks (Chelle-Michou et al., 2017). We thus propose that Velay paragneisses are akin to the Brioverian sediments and that the VOF is the counterpart of the Mancellian granitoids.

However, when compared to the VOF, Mancellian plutonic rocks show a larger petrographic diversity as they include mafic to intermediate rocks which are not observed in the VOF. Accordingly, the Mancellian suite displays a larger scatter in $\mathrm{SiO}_{2}$ contents (49-78 wt.\%) than the VOF (69-79 wt.\%) (Fig. 15a). Moreover, the dominant phase of the Mancellian suite is a granodiorite as opposed to a granite and leucogranites only form subordinate massifs. The Mancellian granodiorites trend between two endmembers in the ternary $\mathrm{CaO}-\mathrm{K}_{2} \mathrm{O} / \mathrm{Na}_{2} \mathrm{O}-$ $\mathrm{Al}_{2} \mathrm{O}_{3} /\left(\mathrm{FeO}_{\mathrm{t}}+\mathrm{MgO}\right)$ diagram (Laurent et al., 2014) (Fig. 15b). This observation suggests a dual origin by: (i) melting of sedimentary materials in agreement with petrographic (Brown, 1995) and isotopic data (D'Lemos and Brown, 1993) ; (ii) involvement of K-rich mantle-derived magmas (Fig. 15b), either as a component of the source (remelting of underplated mafic rocks) and/or via magma mixing/mingling as suggested by the occurrence of mafic microgranular enclaves (Jonin, 1981) and the presence of mafic/intermediate calc-alkaline rocks as part of the suite (Le Gall and Barrat, 1987). Leucogranites have been interpreted as sediment-derived melts produced under high $\mathrm{a}_{(\mathrm{H} 2 \mathrm{O})}$ conditions and are not genetically linked to the granodiorites (Brown, 1995). As a result, the respective petrogenesis of Mancellian and VOF granitoid suites contrast by the extent of mantle contribution (respectively significant vs. lacking) and the relative role played by fractionation in accounting for the most felsic compositions. 
The proposed geodynamic setting for Mancellian magmatism corresponds to the post-570 Ma inversion of a back-arc basin (the Brioverian sequence) in a transpressional regime coeval with collision between the Cadomian arc and the Gondwana continent (Chantraine et al., 2001; Dallmeyer et al., 1991; Linnemann et al., 2014). Given the evidence for limited thickening (maximum crustal thickness of $\sim 40 \mathrm{~km}$ according to Ballèvre et al., 2001) and the presence of a mantle component in the Mancellian suite, crustal melting is considered to have been triggered by the underplating of mafic magmas (Ballèvre et al., 2001; Dissler et al., 1988; Linnemann et al., 2014). In contrast, the lack of substantial evidence for mantle-derived magmatism in the VOF despite its large surface $\left(\sim 1800 \mathrm{~km}^{2}\right)$, especially the invariably (leuco)granitic character and high $\mathrm{SiO}_{2}$ content ( $>68$ wt.\%) of the samples (see Fig. 6 ), rules out mafic magma underplating as a potential heat source. The Cadomian back-arc basin corresponded to stretched and thinned continental crust (Brown and D'Lemos, 1991; Chantraine et al., 2001; Linnemann et al., 2014) and by analogy with modern back-arc settings, high mantle heat flow was expected in this crust segment (Currie and Hyndman, 2006). As demonstrated by Clark et al. (2011), thermal relaxation following stacking of back-arc units generates temperatures in the middle crust in excess of $750^{\circ} \mathrm{C}$, compatible with extensive melting of sedimentary lithologies and with the conditions of formation inferred for the VOF parental magmas based on experimental constraints and zircon saturation (see above). Therefore, limited thickening of anomalously warm Cadomian back-arc basins would have triggered significant crustal melting (Brown and D'Lemos, 1991). As a result, we propose that the VOF is a lateral equivalent of the Mancellian batholith in an area unaffected by mantle melting during the Cadomian back-arc basin inversion. Several reasons can explain the apparent lack of coeval mantle-derived magmatism including: (i) previous depletion of the underlying mantle during back-arc spreading as evidenced by the $590-570$ Ma tholeiitic to calc-alkaline mafic magmatism observed in parts of the Northern Armorican Massif (Chantraine et al., 2001; Linnemann et al., 2014); or (ii) lateral variations in the Cadomian subducting slab dynamics with localized break-off that strongly affected the thermal regime of the back-arc mantle (Nance et al., 2010).

\section{Conclusion}


Remnants of a Cadomian basement are described in the Velay area (eastern French Massif Central) where an S-type granitic suite intruded Ediacaran sediments at c. $542 \mathrm{Ma}$. The main phase of this large $\left(\sim 1800 \mathrm{~km}^{2}\right)$ batholith corresponded to a porphyritic granite (transformed into an augen gneiss during the Variscan orogeny) while some magmas evolved by fractional crystallization towards leucogranitic compositions (corresponding to the present-day leucogneisses). Such voluminous magmatism was likely caused by the inversion of a back-arc basin domain at the end of the Cadomian orogeny, leading to limited stacking of supracrustal sequences in a high thermal regime that favored significant melting. This is supported by the homogeneous $\varepsilon \mathrm{Hf}(\mathrm{t})$ of the VOF zircons compared with their inferred protoliths (sediments derived from various Gondwana-related reservoirs with extremely contrasted isotopic signatures) which points to dissolution of detrital zircons in the source and rapid cooling upon emplacement. From a crust evolution perspective, the Cadomian magmatism in the Velay area was strictly crust-derived and thus attests for substantial reworking of older crust away from a proper continent-continent collision zone. Conversely, there is currently no compelling evidence for Cadomian crust production in the FMC.

\section{Acknowledgements}

We acknowledge funding from the European Commission, together with the UJM through the Campus France PRESTIGE program to C.C.-M.; and with Université de Liège through the MarieCurie Actions Be-IPD-COFUND program to O.L. PB acknowledges support from ERC Starting Grant (MASE; 279828), and his Auvergne Fellowship (French Government Laboratory of Excellence initiative $n^{\circ}$ ANR-10-LABX-0006, ClerVolc contribution $\left.n^{\circ} 255\right)$. We thank C. Guilbaud for making the thin sections, S. Sao-Joao and J.-L. Devidal for assistance during SEM

imaging and B. Moine for help during zircon separation. We are indebted to M. Ballèvre who provided the file of Figure 1. M. J. Mayne, G. Nicoli, A. Aubray, V. Gardien and A. Villaros are thanked for assistance on the field and fruitful discussions. Constructive reviews from P. Barbey and J. Melleton on an early version of this manuscript were very much appreciated.

\section{References}


Aitchison, J., 1986. The Statistical Analysis of Compositional Data. Chapman and Hall, London, UK.

Alexandre, P., 2007. U-Pb zircon SIMS ages from the French Massif Central and implication for the pre-Variscan tectonic evolution in Western Europe. Comptes Rendus Geoscience 339, 613-621.

Alexandrov, P., Floc'h, J.-P., Cuney, M., Cheilletz, A., 2001. Ion microprobe dating of zircons from the Upper Gneiss Unit (South Limousin, Massif Central, France). Comptes Rendus de l'Académie des Sciences, Paris 332, 625-632.

Alvaro, J.J., Bauluz, B., Clausen, S., Devaere, L., Gil Imaz, A., Monceret, E., Vizcaïno, D., 2014. Stratigraphic review of the Cambrian-Lower Ordovician volcanosedimentary complexes from the northern Montagne Noire. Stratigraphy 11, 83-96.

Annen, C., Blundy, J.D., Sparks, R.S.J., 2006. The Genesis of Intermediate and Silicic Magmas in Deep Crustal Hot Zones. Journal of Petrology 47, 505-539.

Appleby, S.K., Gillespie, M.R., Graham, C.M., Hinton, R.W., Oliver, G.J.H., Kelly, N.M., 2009. Do S-type granites commonly sample infracrustal sources? New results from an integrated $\mathrm{O}, \mathrm{U}-\mathrm{Pb}$ and $\mathrm{Hf}$ isotope study of zircon. Contributions to Mineralogy and Petrology 160, $115-132$.

Ballèvre, M., Le Goff, E., Hébert, R., 2001. The tectonothermal evolution of the Cadomian belt of northern Brittany, France: a Neoproterozoic volcanic arc. Tectonophysics 331, 19-43.

Ballouard, C., Boulvais, P., Poujol, M., Gapais, D., Yamato, P., Tartèse, R., Cuney, M., 2015. Tectonic record, magmatic history and hydrothermal alteration in the Hercynian Guérande leucogranite, Armorican Massif, France. Lithos 220-223, 1-22.

Be Mezeme, E., Cocherie, A., Faure, M., Legendre, O., Rossi, P., 2006. Electron microprobe monazite geochronology of magmatic events: Examples from Variscan migmatites and granitoids, Massif Central, France. Lithos 87, 276-288.

Bea, F., 1996. Residence of REE, Y, Th and U in granites and crustal protoliths; implications for the chemistry of crustal melts. Journal of Petrology 37, 521-552.

Bea, F., Pereira, M.D., Corretgé, L.G., Fershtater, G.B., 1994. Differentiation of strongly peraluminous, phosphorus granites: the Pedrobernardo pluton, central Spain. Geochimica et Cosmochimica Acta 58, 2609-2627.

Blundy, J., Cashman, K., 2001. Ascent-driven crystallisation of dacite magmas at Mount St Helens, 1980-1986. Contributions to Mineralogy and Petrology 140, 631-650.

Boehnke, P., Watson, E.B., Trail, D., Harrison, T.M., Schmitt, A.K., 2013. Zircon saturation rerevisited. Chemical Geology 351, 324-334.

Bouilhol, P., Leyreloup, A.F., Delor, C., Vauchez, A., Monié, P., 2006. Relationships between lower and upper crust tectonic during doming: the mylonitic southern edge of the Velay metamorphic core complex (Cévennes-French Massif Central). Geodinamica Acta 19, 137153. 
Bouvier, A., Vervoort, J.D., Patchett, P.J., 2008. The Lu-Hf and Sm-Nd isotopic composition of CHUR: Constraints from unequilibrated chondrites and implications for the bulk composition of terrestrial planets. Earth and Planetary Science Letters 273, 48-57.

Boynton, W.V., 1984. Cosmochemistry of the rare earth elements: meteorite studies, In: Henderson, P. (Ed.), Rare Earth Element Geochemistry. Elsevier, Amsterdam, pp. 63-114.

Briand, B., Bouchardon, J.-L., Santallier, D., Piboule, M., Ouali, H., Capiez, P., 1992. Alkaline affinity of the metabasites in the gneissic series surrounding the Velay migmatitic domain. Géologie de la France 2, 9-15.

Brown, M., 1995. The late-Precambrian geodynamic evolution of the Armorica segment of the Cadomian belt (France): Distortion of an active continental margin during south-west directed convergence and subduction of a bathymetric high. Géologie de la France 3, 3-22.

Brown, M., D'Lemos, R.S., 1991. The Cadomian granites of Mancellia, northeast Armorican Massif of France: relationship to the St. Malo migmatite belt, petrogenesis and tectonic setting. Precambrian Research 51, 393-427.

Buccianti, A., Peccerillo, A., 1999. The complex nature of potassic and ultrapotassic magmatism in Central-Southern Italy: a multivariate analysis of major element data, In: Lippard, S.J., Naess, A., Sinding-Larsen, R. (Eds.), 5th Annual Conference of the International Association for Mathematical Geology Trondheim, Tapir, pp. 145-150.

Burg, J.-P., Van Den Driessche, J., Brun, J.P., 1994. Syn- to post-thickening extension in the Variscan Belt of Western Europe: Modes and structural consequences. Géologie de la France $3,33-51$.

Caen-Vachette, M., 1979. Age cambrien des rhyolites transformées en leptynites dans la série métamorphique du Pilat (Massif Central français). Comptes Rendus de l'Académie des Sciences, Paris 289, 997-1000.

Cawood, P.A., Kröner, A., Collins, W.J., Kusky, T.M., Mooney, W.D., Windley, B.F., 2009. Accretionary orogens through Earth history. Geological Society, London, Special Publications 318, 1-36.

Chantraine, J., Egal, E., Thiéblemont, D., Le Goff, E., Guerrot, C., Ballèvre, M., Guennoc, P., 2001. The Cadomian active margin (Northern Armorican Massif, France): a segment of the North Atlantic Panafrican belt. Tectonophysics 331, 1-18.

Chappell, B.W., White, A.J.R., 2001. Two contrasting granite types: 25 years later. Australian Journal of Earth Sciences 48, 489-499.

Chelle-Michou, C., Laurent, O., Moyen, J.-F., Block, S., Paquette, J.-L., Couzinié, S., Gardien, V., Vanderhaeghe, O., Villaros, A., Zeh, A., 2017. Pre-Cadomian to late-Variscan odyssey of the eastern Massif Central, France: Formation of the West European crust in a nutshell. Gondwana Research 46, 170-190.

Chenevoy, M., Gay, M., Lochon, P., 1986. Metamorphic alkali-basalts and leucogranites in the Western Vivarais series (French Central Massif): a record of two major tectonic events in paleozoic time. Comptes Rendus de l'Académie des Sciences, Paris 303, 725-730. 
Clark, C., Fitzsimons, I.C.W., Healy, D., Harley, S.L., 2011. How Does the Continental Crust Get Really Hot? Elements 7, 235-240.

Clemens, J.D., Petford, N., Mawer, C.K., 1997. Ascent mechanisms of granitic magmas: causes and consequences, in: Holness, M.B. (Ed.), Deformation-enhanced fluid transport in the Earth's crust and mantle. Mineralogical Society Series pp. 145-172.

Coldwell, B., Clemens, J., Petford, N., 2011. Deep crustal melting in the Peruvian Andes: Felsic magma generation during delamination and uplift. Lithos 125, 272-286.

Corfu, F., Hanchar, J.M., Hoskin, P.W.O., Kinny, P.D., 2003. Atlas of Zircon Textures. Reviews in Mineralogy and Geochemistry 53, 469-500.

Couzinié, S., Laurent, O., Moyen, J.F., Zeh, A., Bouilhol, P., Villaros, A., 2016. Post-collisional magmatism: Crustal growth not identified by zircon Hf-O isotopes. Earth and Planetary Science Letters 456, 182-195.

Couzinié, S., Moyen, J.F., Villaros, A., Paquette, J.L., Scarrow, J.H., Marignac, C., 2014. Temporal relationships between Mg-K mafic magmatism and catastrophic melting of the Variscan crust in the southern part of Velay Complex (Massif Central, France). Journal of Geosciences, 6986.

Currie, C.A., Hyndman, R.D., 2006. The thermal structure of subduction zone back arcs. Journal of Geophysical Research 111.

D'Lemos, R.S., Brown, M., 1993. Sm-Nd isotope characteristics of late Cadomian granite magmatism in northern France and the Channel Islands. Geological Magazine 130, 797-804.

Dallmeyer, R.-D., Strachan, R.A., D'Lemos, R.S., 1991. Chronology of Cadomian tectonothermal activity in the baie de Saint-Brieux (North Brittany), France: evidence from ${ }^{40} \mathrm{Ar} /{ }^{39} \mathrm{Ar}$ mineral ages. Canadian Journal of Earth Sciences 28, 762-773.

Dewey, J.F., Hempton, M.R., Kidd, W.S.F., Saroglu, F., Şengör, A.M.C., 1986. Shortening of continental lithosphere: the neotectonics of Eastern Anatolia - a young collision zone, in: Coward, M.P., Ries, A.C. (Eds.), Collision Tectonics. Geological Society, London, Special Publications, pp. 3-36.

Dissler, E., Doré, F., Dupret, L., Gresselin, F., Le Gall, J., 1988. Cadomian geodynamical evolution in the northeastern Armorican massif. Bulletin de la Société Géologique de France 8, 801814.

Duthou, J.-L., Cantagrel, J.-M., Didier, J., Vialette, Y., 1984. Palaeozoic granitoids from the French Massif Central: age and origin studied by ${ }^{87} \mathrm{Rb}^{87} \mathrm{Sr}$ system. Physics of the Earth and Planetary Interiors 35, 131-144.

Egal, E., Guennoc, P., Le Goff, E., Thiéblemont, D., Lebret, P., Hallégouet, B., 1996. The Cadomian orogeny revisited in northern Brittany, Avalonian and Related Peri-Gondwanan Terranes of the Circum-North Atlantic. Geological Society of America, Special Publication, pp. 218-318. 
Egal, E., Hallegouët, B., Le Goff, E., Schroetter, J.-M., Mougin, B., Cocherie, A., Langouët, L., Monnier, J.-L., Théveniaut, H., Thiéblemont, D., Thomas, E., 2011. Notice explicative, Carte géol. France (1/50 000), feuille Dinan (245). BRGM, Orléans, p. 196.

Farina, F., Stevens, G., Gerdes, A., Frei, D., 2014. Small-scale Hf isotopic variability in the Peninsula pluton (South Africa): the processes that control inheritance of source ${ }^{176} \mathrm{Hf} /{ }^{177} \mathrm{Hf}$ diversity in S-type granites. Contributions to Mineralogy and Petrology 168.

Faure, M., Brouder, P., Thierry, J., Alabouvette, B., Cocherie, A., Bouchot, V., 2009a. Notice explicative, Carte géol. France (1/50 000), feuille Saint-André-de-Valborgne (911). BRGM, Orléans, p. 138.

Faure, M., Lardeaux, J.-M., Ledru, P., 2009b. A review of the pre-Permian geology of the Variscan French Massif Central. Comptes Rendus Geoscience 341, 202-213.

Finney, S.C., Gibbard, P.L., Fan, J.X., 2013. The ICS International Chronostratigraphic Chart. Episodes 36, 199-204.

Fournier-Vinas, C., Debat, P., 1970. Présence de micro-organismes dans les terrains métamorphiques précambriens (schistes X) de l'Ouest de la Montagne Noire. Bulletin de la Société Géologique de France 7, 351-355.

Frost, B.R., Frost, C.D., 2008. On charnockites. Gondwana Research 13, 30-44.

Gardien, V., Lardeaux, J.M., Ledru, P., Allemand, P., Guillot, S., 1997. Metamorphism during late orogenic extension : insights from the French Variscan belt. Bulletin de la Société Géologique de France 168, 271-286.

Garfunkel, Z., 2015. The relations between Gondwana and the adjacent peripheral Cadomian domain - constrains on the origin, history, and paleogeography of the peripheral domain. Gondwana Research 28, 1257-1281.

Gerdes, A., Zeh, A., 2006. Combined U-Pb and Hf isotope LA-(MC-)ICP-MS analyses of detrital zircons: Comparison with SHRIMP and new constraints for the provenance and age of an Armorican metasediment in Central Germany. Earth and Planetary Science Letters 249, 4761.

Gerdes, A., Zeh, A., 2009. Zircon formation versus zircon alteration - New insights from combined $\mathrm{U}-\mathrm{Pb}$ and $\mathrm{Lu}-\mathrm{Hf}$ in-situ LA-ICP-MS analyses, and consequences for the interpretation of Archean zircon from the Central Zone of the Limpopo Belt. Chemical Geology 261, 230-243.

Griffin, W.L., Wang, X., Jackson, S.E., Pearson, N.J., O’Reilly, S.Y., Xu, X.-S., Zhou, X., 2002. Zircon chemistry and magma mixing, SE China: In-situ analysis of Hf isotopes, Tonglu and Pingtan igneous complexes. Lithos 61, 237-269.

Guérangé-Lozes, J., Burg, J.-P., 1990. Variscan nappes in the southwest of the Massif Central (1:250 000 geological and structural maps of Montpellier and Aurillac). Géologie de la France 3-4, 71-106. 
Harris, N.B.W., Pearce, J.A., Tindle, A.G., 1986. Geochemical characteristics of collision-zone magmatism, in: Coward, M.P., Ries, A.C. (Eds.), Collision Tectonics. Geological Society, London, Special Publications, pp. 67-81.

Hawkesworth, C., Cawood, P., Kemp, T., Storey, C., Dhuime, B., 2009. A matter of preservation. Science 323, 49-50.

Hawkesworth, C.J., Dhuime, B., Pietranik, A.B., Cawood, P.A., Kemp, A.I.S., Storey, C.D., 2010. The generation and evolution of the continental crust. Journal of the Geological Society 167, 229-248.

Holtz, F., Johannes, W., 1994. Maximum and minimum water content of granitic meltsimplications for chemical and physical properties of ascending magmas. Lithos 32, 149-159.

Ihaka, R., Gentleman, R., 1996. R: a language for data analysis and graphics. Journal of Computational and Graphical Statistics 5, 299-344.

Jackson, S.E., Pearson, N.J., Griffin, W.L., Belousova, E.A., 2004. The application of laser ablation-inductively coupled plasma-mass spectrometry to in situ U-Pb zircon geochronology. Chemical Geology 211, 47-69.

Jagoutz, O., Kelemen, P.B., 2015. Role of Arc Processes in the Formation of Continental Crust. Annual Review of Earth and Planetary Sciences 43, 363-404.

Janoušek, V., Braithwaite, C.J.R., Bowes, D.R., Gerdes, A., 2004. Magma-mixing in the genesis of Hercynian calc-alkaline granitoids: an integrated petrographic and geochemical study of the Sázava intrusion, Central Bohemian Pluton, Czech Republic. Lithos 78, 67-99.

Janoušek, V., Farrow, C.M., Erban, V., 2006. Interpretation of Whole-rock Geochemical Data in Igneous Geochemistry: Introducing Geochemical Data Toolkit (GCDkit). Journal of Petrology 47, 1255-1259.

Johannes, W., Holtz, F., 1996. Petrogenesis and experimental petrology of granitic rocks. Springer, Berlin Heidelberg New York.

Jonin, M., 1981. Un batholite fini-Précambrien : le batholite mancellien (Massif Armoricain, France). Etude pétrographique et géochimique. Brest, p. 638.

Kroner, U., Romer, R.L., 2013. Two plates - Many subduction zones: The Variscan orogeny reconsidered. Gondwana Research 24, 298-329.

Lagarde, J.-L., Dallain, C., 1994. Strain patterns within the late Variscan granitic dome of Velay, French Massif Central. Journal of Structural Geology 16, 839-852.

Lardeaux, J.M., Schulmann, K., Faure, M., Janou ek, V., Lexa, O., Skrzypek, E., Edel, J.B., tipska, P., 2014. The Moldanubian Zone in the French Massif Central, Vosges/Schwarzwald and Bohemian Massif revisited: differences and similarities. Geological Society, London, Special Publications 405, 7-44.

Laurent, O., Couzinié, S., Zeh, A., Vanderhaeghe, O., Moyen, J.-F., Villaros, A., Gardien, V., Chelle-Michou, C., 2017. Protracted, coeval crust and mantle melting during Variscan lateorogenic evolution: $\mathrm{U}-\mathrm{Pb}$ dating in the eastern French Massif Central. International Journal of Earth Sciences 106, 421-451.Laurent, O., Martin, H., Moyen, J.F., Doucelance, R., 2014. 
The diversity and evolution of late-Archean granitoids: Evidence for the onset of "modernstyle" plate tectonics between 3.0 and $2.5 \mathrm{Ga}$. Lithos 205, 208-235.

Le Gall, J., Barrat, J.A., 1987. Petrology of late Cadomian magmatism in the northern Armorican Massif; the Ernee and Tregomar mafic and ultramafic complexes. Géologie de la France 1, $3-22$.

Ledru, P., Courrioux, G., Dallain, C., Lardeaux, J.M., Montel, J.M., Vanderhaeghe, O., Vitel, G., 2001. The Velay dome (French Massif Central): melt generation and granite emplacement during orogenic evolution. Tectonophysics 342, 207-237.

Ledru, P., Lardeaux, J.M., Santallier, D., Autran, A., Quenardel, J.-M., Floc'h, J.-P., Lerouge, G., Maillet, N., Marchand, J., Ploquin, A., 1989. Where are the nappes in the French Massif central? Bulletin de la Société Géologique de France 8, 605-618.

Ledru, P., Vitel, G., Marchand, J., Maurin, G., Mercier, F., Turland, M., Etlicher, B., Dautria, J.M., Liotard, J.M., 1994. Notice explicative, Carte géol. France (1/50 000), feuille Craponne-surArzon (767). BRGM, Orléans, p. 74.

Lescuyer, J.-L., Cocherie, A., 1992. Single-zircon dating of the Sériès meta-dacites: evidence for a Late Proterozoic age of the "X Schists" from Montagne Noire (Southern French Massif Central). Comptes Rendus de l'Académie des Sciences, Paris 314, 1071-1077.

Linnemann, U., Gerdes, A., Hofmann, M., Marko, L., 2014. The Cadomian Orogen: Neoproterozoic to Early Cambrian crustal growth and orogenic zoning along the periphery of the West African Craton-Constraints from U-Pb zircon ages and $\mathrm{Hf}$ isotopes (Schwarzburg Antiform, Germany). Precambrian Research 244, 236-278.

Ludwig, K.R., 2008. A Geochronological Toolkit for Microsoft Excel, Berkeley Geochronology Central Special Publication, p. 76.

Malavielle, J., Guihot, P., Costa, S., Lardeaux, J.M., Gardien, V., 1990. Collapse of the thickened Variscan crust in the French Massif Central: Mont Pilat extensional shear zone and St. Etienne Late Carboniferous basin. Tectonophysics 177, 139-149.

Marini, F., 1987. Relictual clinopyroxenes in paleozoic metabasites from Albigeois: tracers of a distensive transitional-to-tholeiitic volcanism ("Schistes et Roches Vertes" formation, Tarn, probable ordovician age). Comptes Rendus de l'Académie des Sciences, Paris 304, 29-34.

Matte, P., 1986. Tectonics and plate tectonics model for the Variscan belt of Europe. Tectonophysics 126, 329-374.

McDonough, W.F., Sun, S.-s., 1995. The composition of the Earth. Chemical Geology 120, 223253.

Melleton, J., Cocherie, A., Faure, M., Rossi, P., 2010. Precambrian protoliths and Early Paleozoic magmatism in the French Massif Central: U-Pb data and the North Gondwana connection in the west European Variscan belt. Gondwana Research 17, 13-25.

Middlemost, E.A.K., 1994. Naming materials in the magma/igneous rock system. Earth Science Review 37, 215-224. 
Montel, J.M., Marignac, C., Barbey, P., Pichavant, M., 1992. Thermobarometry and granite genesis: the Hercynian low-P, high-T Velay anatectic dome (French Massif Central). Journal of Metamorphic Geology 10, 1-15.

Morel, M.L.A., Nebel, O., Nebel-Jacobsen, Y.J., Miller, J.S., Vroon, P.Z., 2008. Hafnium isotope characterization of the GJ-1 zircon reference material by solution and laser-ablation MCICPMS. Chemical Geology 255, 231-235.

Mougeot, R., Respaut, J.P., Ledru, P., Marignac, C., 1997. U-Pb chronology on accessory minerals of the Velay anatectic dome (French Massif Central). European Journal of Mineralogy 9, $141-156$.

Moyen, J.F., Laurent, O., Chelle-Michou, C., Couzinié, S., Vanderhaeghe, O., Zeh, A., Villaros, A., Gardien, V., 2017. Collision vs. subduction-related magmatism: Two contrasting ways of granite formation and implications for crustal growth. Lithos 277, 154-177.Naeraa, T., Schersten, A., Rosing, M.T., Kemp, A.I., Hoffmann, J.E., Kokfelt, T.F., Whitehouse, M.J., 2012. Hafnium isotope evidence for a transition in the dynamics of continental growth 3.2 Gyr ago. Nature 485, 627-630.

Nance, R.D., Gutiérrez-Alonso, G., Keppie, J.D., Linnemann, U., Murphy, J.B., Quesada, C., Strachan, R.A., Woodcock, N.H., 2010. Evolution of the Rheic Ocean. Gondwana Research 17, 194-222.

Nance, R.D., Murphy, J.B., Strachan, R.A., D'Lemos, R.S., Taylor, G.K., 1991. Late Proterozoic tectonostratigraphic evolution of the Avalonian and Cadomian terranes. Precambrian Research 53, 41-78.

Niu, Y., Zhao, Z., Zhu, D.-C., Mo, X., 2013. Continental collision zones are primary sites for net continental crust growth - A testable hypothesis. Earth-Science Reviews 127, 96-110.

Reymer, A., Schubert, G., 1984. Phanerozoic addition rates to the continental crust and crustal growth. Tectonics 3, 63-77.

Ohta, T., Arai, H., 2007. Statistical empirical index of chemical weathering in igneous rocks: A new tool for evaluating the degree of weathering. Chemical Geology 240, 280-297.

Orejana, D., Merino Martínez, E., Villaseca, C., Andersen, T., 2015. Ediacaran-Cambrian paleogeography and geodynamic setting of the Central Iberian Zone: Constraints from coupled U-Pb-Hf isotopes of detrital zircons. Precambrian Research 261, 234-251.

Paquette, J.-L., Piro, J.-L., Devidal, J.-L., Bosse, V., Didier, A., Sanac, S., Abdelnour, Y., 2014. Sensitivity enhancement in LA-ICP-MS by $\mathrm{N}_{2}$ addition to carrier gas: Application to radiometric dating of U-Th-bearing minerals. Agilent ICP-MS Journal 58, 1-5.

Peucat, J.J., 1986. Behaviour of Rb-Sr whole-rock and U-Pb zircon systems during partial melting as shown in migmatitic gneisses from the Saint-Malo Massif, NE Brittany, France. Journal of the Geological Society, London 143, 875-886.

Pin, C., Duthou, J.-L., 1990. Source of Hercynian granitoids from the French Massif Central: Inferences from $\mathrm{Nd}$ isotopes and consequences for crustal evolution. Chemical Geology 83, 281-296. 
Pin, C., Marini, F., 1993. Early Ordovician continental break-up in Variscan Europe: Nd-Sr isotope and trace element evidence from bimodal igneous associations of the Southern Massif Central, France. Lithos 29, 177-196.

Pouclet, A., Álvaro, J.J., Bardintzeff, J.-M., Imaz, A.G., Monceret, E., Vizcaïno, D., 2017. Cambrian-early Ordovician volcanism across the South Armorican and Occitan domains of the Variscan Belt in France: Continental break-up and rifting of the northern Gondwana margin. Geoscience Frontiers 8, 25-64.R'Kha Chaham, K., Couturié, J.-P., Duthou, J.-L., Fernandez, A., Vittel, G., 1990. The Fix augen gneiss (French Massif Central): new evidence for the lower Cambrian peraluminous magmatism. Comptes Rendus de l'Académie des Sciences, Paris 311, 845-850.

Reitz, E., Wickert, F., 1988. Upper Proterozoic microfossils in low-grade phyllites of the BrévenneUnit, NE Massif Central (France). Comptes Rendus de l'Académie des Sciences, Paris 307, $1717-1721$.

Reymer, A., Schubert, G., 1984. Phanerozoic addition rates to the continental crust and crustal growth. Tectonics 3, 63-77.

Roger, F., Teyssier, C., Respaut, J.-P., Rey, P.F., Jolivet, M., Whitney, D.L., Paquette, J.-L., Brunel, M., 2015. Timing of formation and exhumation of the Montagne Noire double dome, French Massif Central. Tectonophysics 640-641, 53-69.

Rogers, J.J.W., Santosh, M., 2003. Supercontinents in Earth History. Gondwana Research 6, 357368.

Scherer, E.E., Münker, C., Mezger, K., 2001. Calibration of the Lutetium-Hafnium Clock. Science 293, 683-687.

Shand, 1943. Eruptive Rocks. John Wiley \& Sons.

Sisson, T.W., Ratajeski, K., Hankins, W.B., Glazner, A.F., 2004. Voluminous granitic magmas from common basaltic sources. Contributions to Mineralogy and Petrology 148, 635-661.

Sláma, J., Košler, J., Condon, D.J., Crowley, J.L., Gerdes, A., Hanchar, J.M., Horstwood, M.S.A., Morris, G.A., Nasdala, L., Norberg, N., Schaltegger, U., Schoene, B., Tubrett, M.N., Whitehouse, M.J., 2008. Plešovice zircon - A new natural reference material for $\mathrm{U}-\mathrm{Pb}$ and Hf isotopic microanalysis. Chemical Geology 249, 1-35.

Söderlund, U., Patchett, P.J., Vervoort, J.D., Isachsen, C.E., 2004. The 176Lu decay constant determined by $\mathrm{Lu}-\mathrm{Hf}$ and $\mathrm{U}-\mathrm{Pb}$ isotope systematics of Precambrian mafic intrusions. Earth and Planetary Science Letters 219, 311-324.

Stampfli, G.M., Hochard, C., Vérard, C., Wilhem, C., von Raumer, J., 2013. The formation of Pangea. Tectonophysics 593, 1-19.

Stevens, G., Villaros, A., Moyen, J.-F., 2007. Selective peritectic garnet entrainment as the origin of geochemical diversity in S-type granites. Geology 35, 9-12.

Tartèse, R., Boulvais, P., 2010. Differentiation of peraluminous leucogranites "en route" to the surface. Lithos 114, 353-368. 
Taylor, S.R., McLennan, S.M., 1985. The Continental Crust: its Composition and Evolution. Blackwell, Oxford.

Teixeira, R.J.S., Neiva, A.M.R., Silva, P.B., Gomes, M.E.P., Andersen, T., Ramos, J.M.F., 2011. Combined $\mathrm{U}-\mathrm{Pb}$ geochronology and $\mathrm{Lu}-\mathrm{Hf}$ isotope systematics by LAM-ICPMS of zircons from granites and metasedimentary rocks of Carrazeda de Ansiães and Sabugal areas, Portugal, to constrain granite sources. Lithos 125, 321-334.

Turpin, L., Cuney, M., Friedrich, M., Bouchez, J.L., Aubertin, M., 1990. Meta-igneous origin of Hercynian peraluminous granites in N.W. French Massif Central: implications for crustal history reconstructions. Contributions to Mineralogy and Petrology 104, 163-172.

Van Achterbergh, E., Ryan, C.G., Jackson, S.E., Griffin, W.L., 2001. Data reduction software for LA-ICP-MS: appendix, In: Sylvester, P.J. (Ed.), Laser Ablation-ICP-Mass Spectrometry in the Earth Sciences: Principles and Applications, . Mineralog Assoc Canada (MAC), Ottawa, Ontario, Canada, pp. 239-243.

Venables, W.N., Ripley, B.D., 2002. Modern Applied Statistics with S, 4th ed. Springer.

Vermeesch, P., 2012. On the visualisation of detrital age distributions. Chemical Geology 312-313, 190-194.

Villaros, A., Buick, I.S., Stevens, G., 2012. Isotopic variations in S-type granites: an inheritance from a heterogeneous source? Contributions to Mineralogy and Petrology 163, 243-257.

Villaseca, C., Merino Martínez, E., Orejana, D., Andersen, T., Belousova, E., 2016. Zircon Hf signatures from granitic orthogneisses of the Spanish Central System: Significance and sources of the Cambro-Ordovician magmatism in the Iberian Variscan Belt. Gondwana Research 34, 60-83.

Williamson, B.J., Downes, H., Thirlwall, M.F., 1992. The relationship between crustal magmatic underplating and granite genesis: an example from the Velay granite complex, Massif Central, France. Transactions of the Royal Society of Edinburgh 83, 235-245.

Woodhead, J., Hergt, J., Shelley, M., Eggins, S., Kemp, R., 2004. Zircon Hf-isotope analysis with an excimer laser, depth profiling, ablation of complex geometries, and concomitant age estimation. Chemical Geology 209, 121-135.

Zurbriggen, R., 2015. Ordovician orogeny in the Alps: a reappraisal. International Journal of Earth Sciences 104, 335-350. 


\section{Figures and Tables}

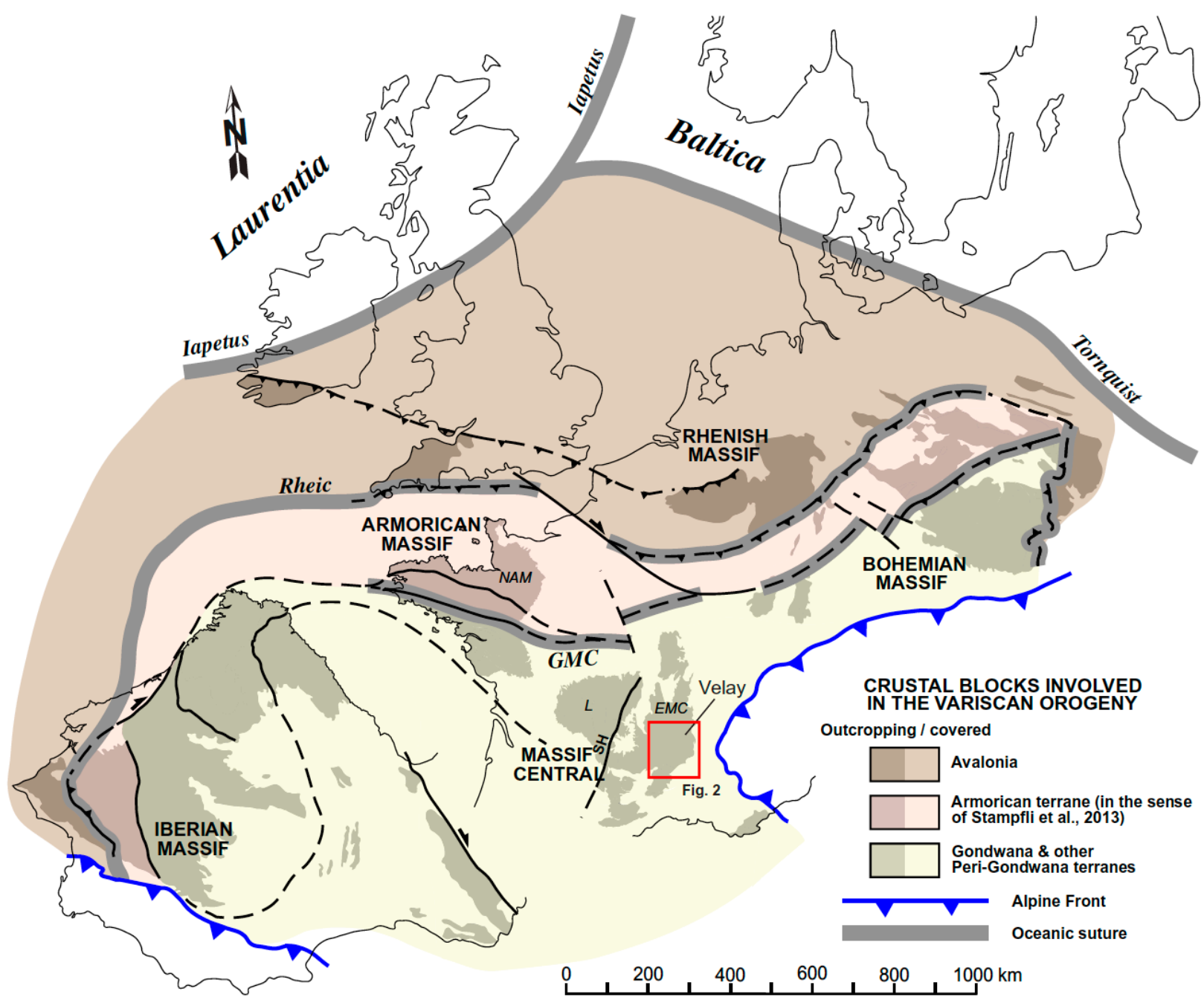

Figure 1: Sketch map of the crustal blocks involved in the Variscan orogeny, adapted from Ballèvre et al. (2014). Yellow star highlights the location of the study area. Oceanic sutures: GMC, Galicia-Massif-Central ocean. Regional subdivisions: NAM, North Armorican Massif; L, Limousin (Western Massif Central); EMC, Eastern Massif Central. Shear zones: SH, Sillon Houiller (coal line). 


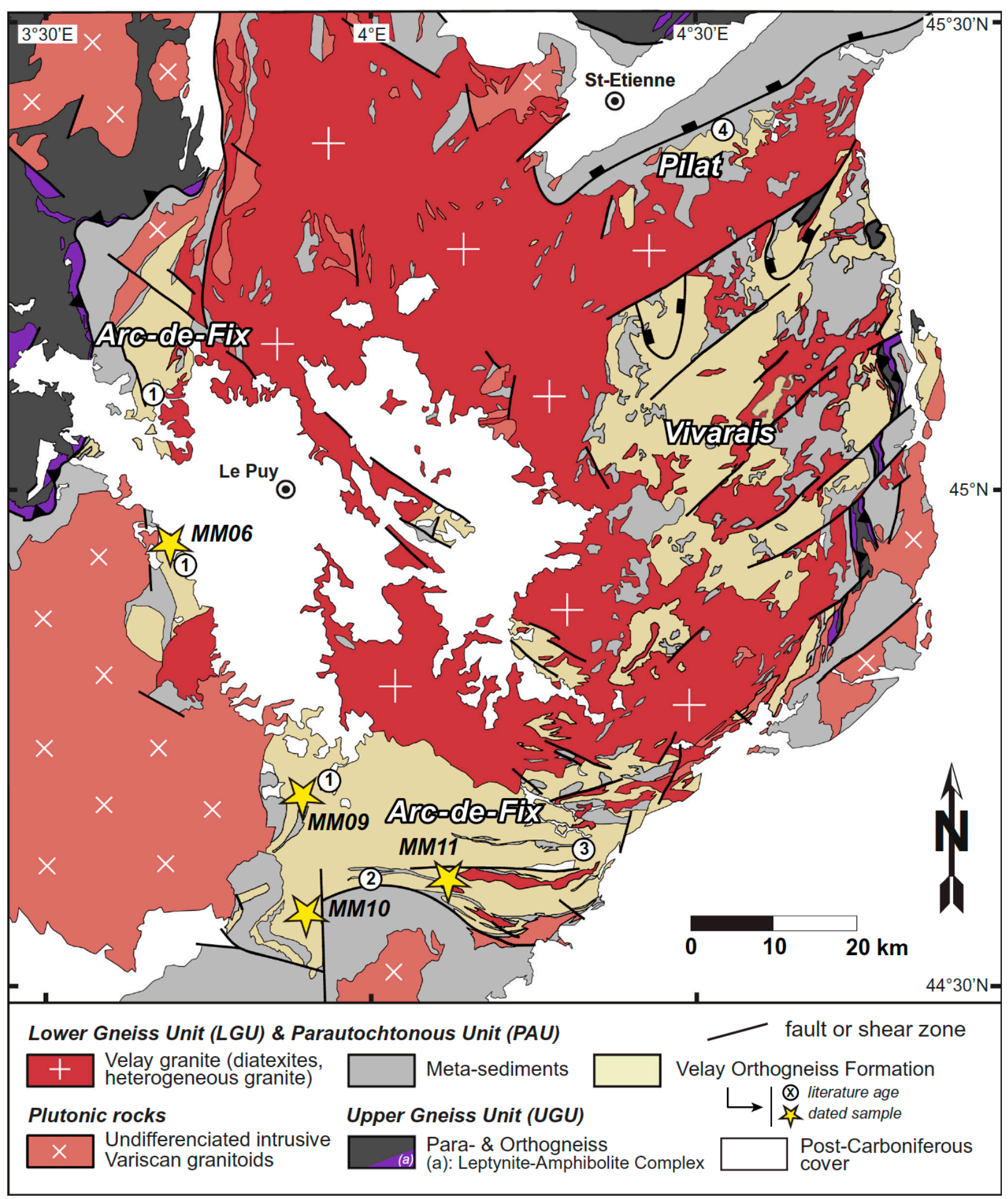

Figure 2: Geological map of the Velay dome area. The extent of Variscan partial melting of the metamorphic lithologies is not shown for sake of clarity. Redrawn after Ledru et al. (2001) and regional geological maps of France at scale 1/50000. 


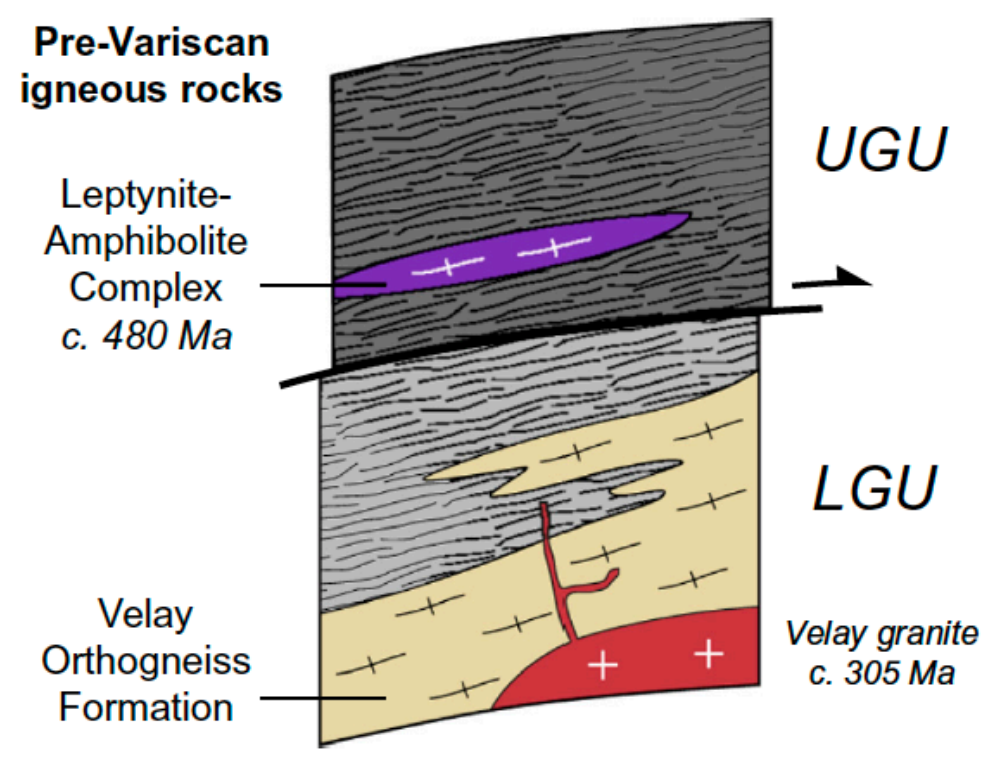

Figure 3: Schematic diagram showing the field relationships and ages of the main lithological components within the two high-grade units (Upper and Lower Gneiss Units) of the eastern French Massif Central. See text for discussion. 

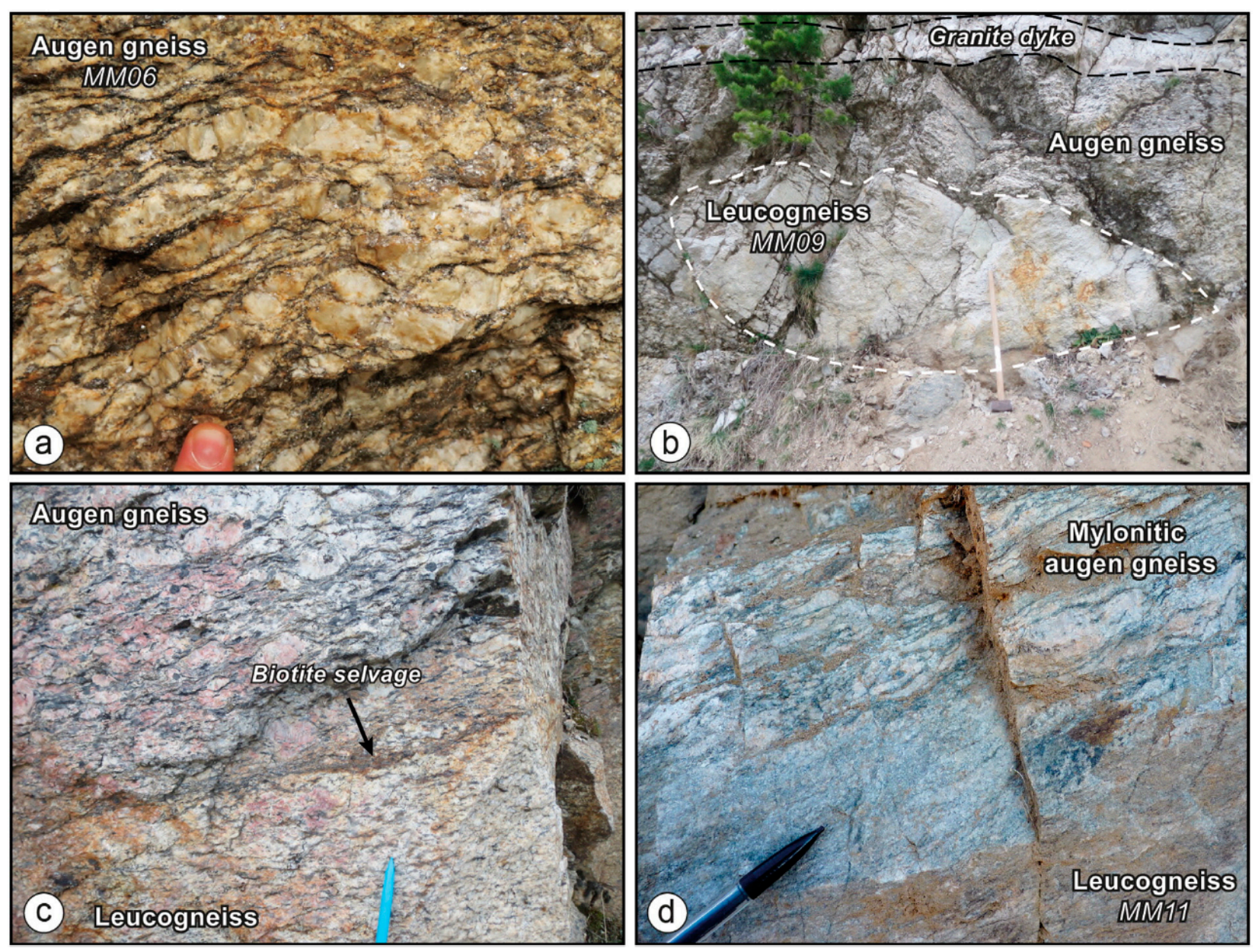

Figure 4: Outcrop photographs showing: (a) a typical biotite + muscovite augen gneiss (dated sample MM06), St Privat-d'Allier; (b) a leucogneiss boudin (dated sample MM09) elongated within the augen gneiss facies, D906 Langogne; (c) sharp contact between the two facies underlined by a biotite-rich layer, D906 Langogne; (d) 10cm-thick laminated layers of mylonitic augen gneiss embedded within strongly deformed leucogneiss, contact is intricate and gradational, Pont-du-Bon-Dieu, Labastide-Puylaurent. 


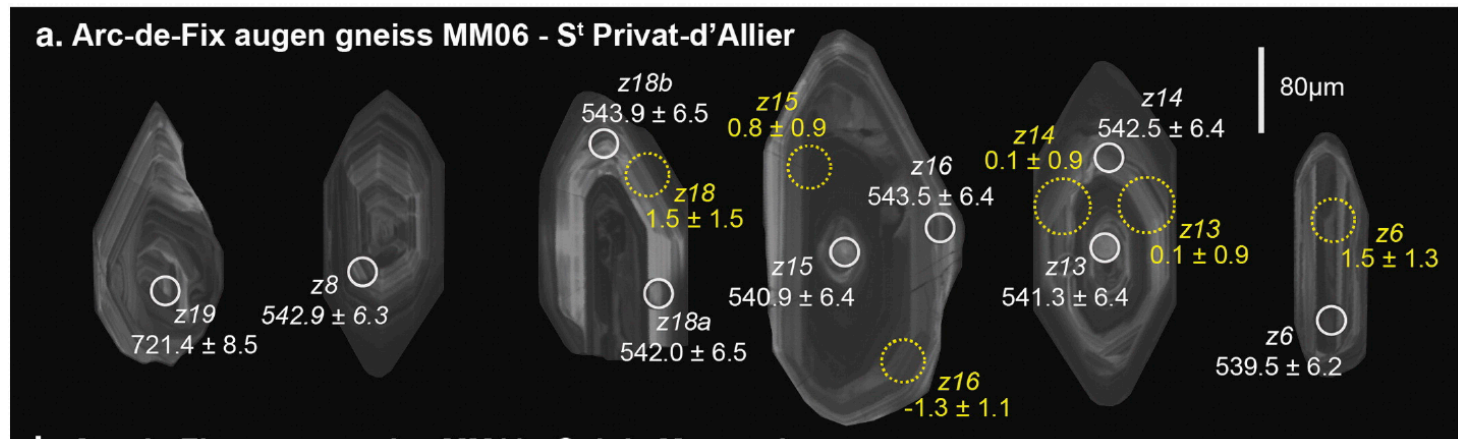

b. Arc-de-Fix augen gneiss MM11 - Col de Meyrand
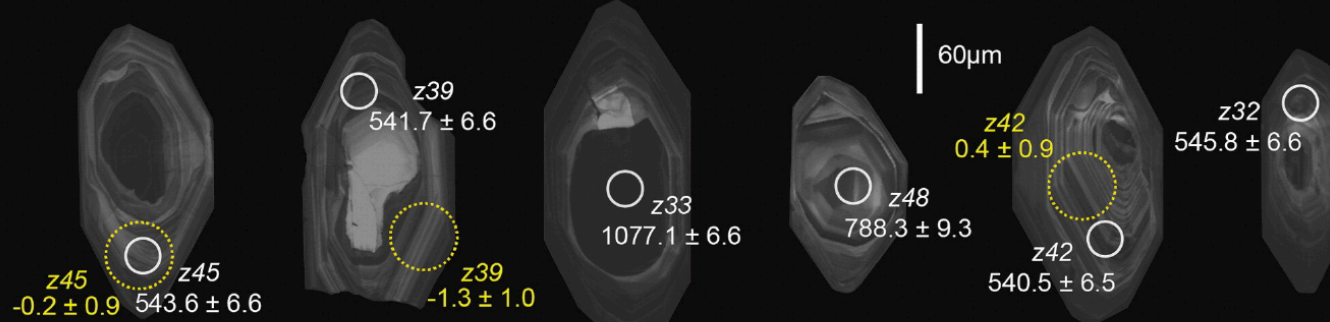

\section{c. Leucogneiss MM10 - Labastide-Puylaurent}
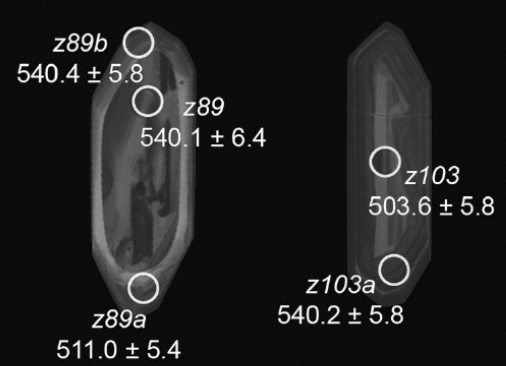

d. Leucogneiss MM09 - Langogne
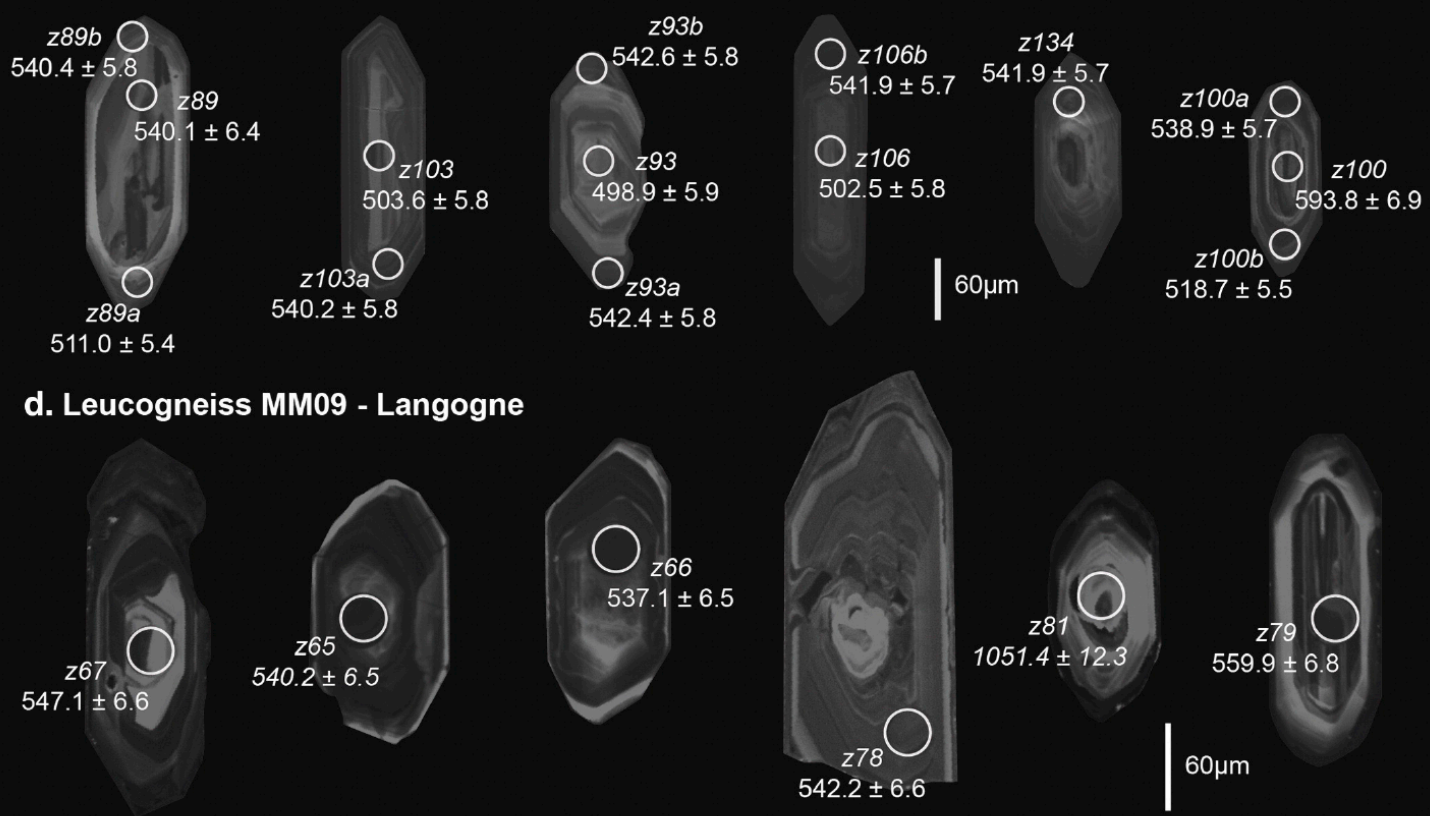

Figure 5: Representative cathodoluminescence images of zircon grains from samples of the Velay Orthogneiss Formation. The locations of laser spots (white and yellow circles for U-Pb and Lu-Hf analyses respectively) are indicated along with the spot name (zXX). The corresponding ${ }^{206} \mathrm{~Pb} /{ }^{238} \mathrm{U}$ dates are quoted with $\pm 2 \sigma$ uncertainty, in Ma. All displayed analyses are concordant at $>98 \%$ (except those in italic). Hf isotope data are reported using the $\varepsilon H f$ calculated at the emplacement age of the corresponding sample, quoted with $\pm 2 \sigma$ uncertainty. 

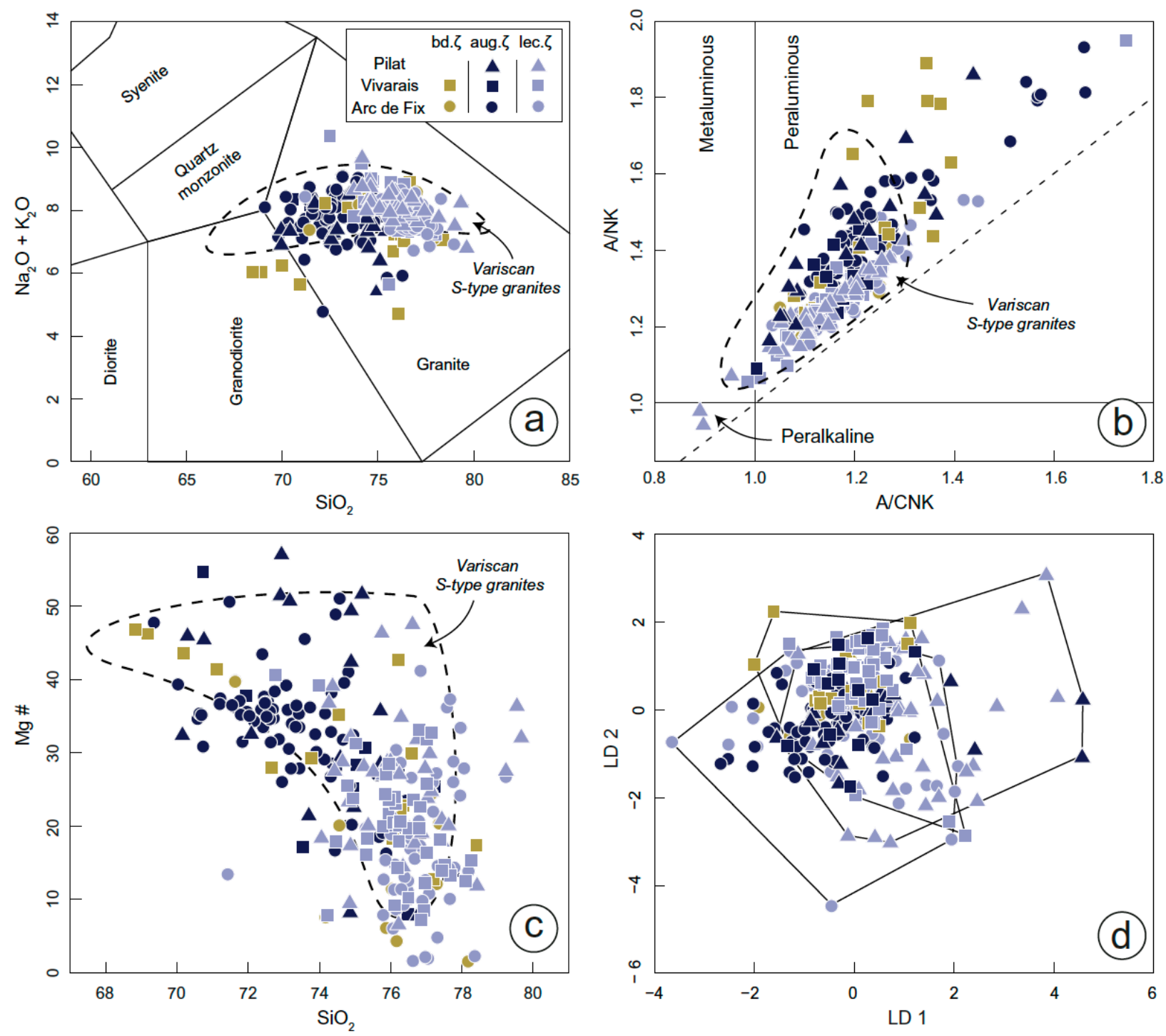

Figure 6: Major elements compositions of samples from the Velay Orthogneiss Formation: (a) $\mathrm{Na}_{2} \mathrm{O}+\mathrm{K}_{2} \mathrm{O}$ vs. $\mathrm{SiO}_{2}$ Middlemost's classification diagram (Middlemost, 1994); (b) A/CNK vs. A/NK Shand's diagram (Shand, 1943); (c) Mg\# vs. $\mathrm{SiO}_{2}$. All diagrams were plotted using the GCDkit software (Janoušek et al., 2006); (d) Results of linear discrimination analysis (LDA) More than $80 \%$ of the data are indistinguishable from one another. Data for Variscan S-type granites are from Moyen et al. (2017). 

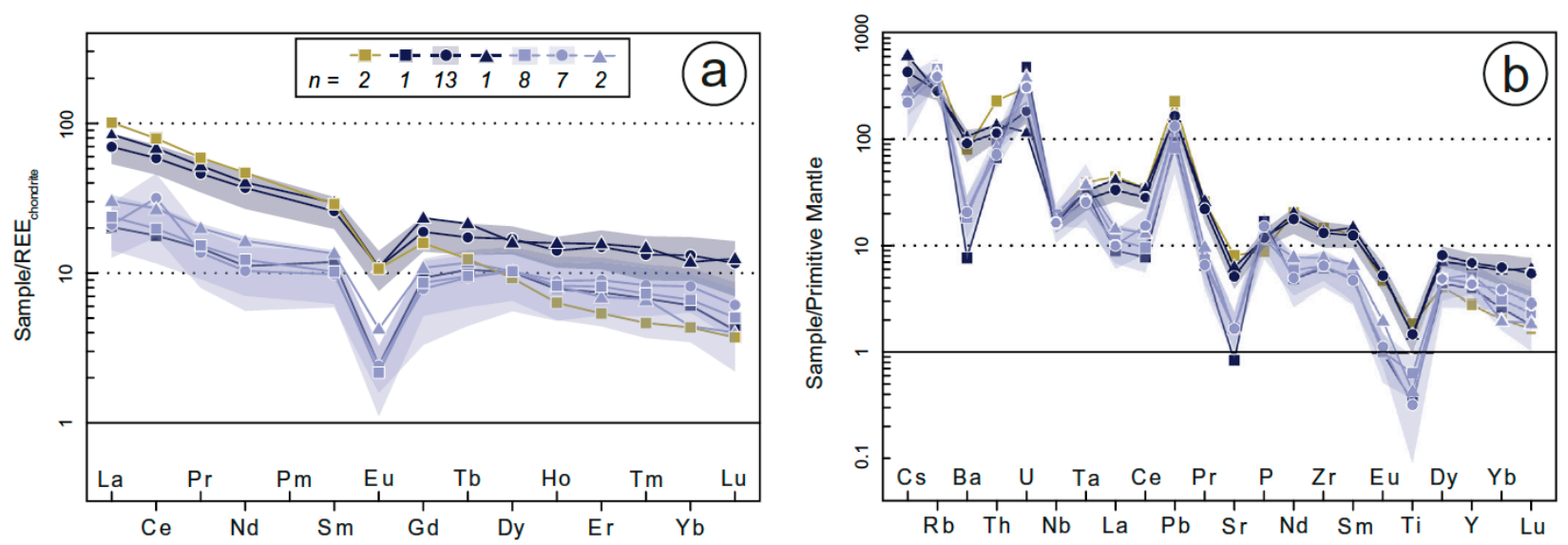

Figure 7: Average trace-elements compositions of rocks from the Velay Orthogneiss Formation: (a) Rare Earth Elements patterns normalized to the chondrite (Boynton, 1984); (b) Coryell-Masuda diagram normalized to the Primitive Mantle (McDonough and Sun, 1995). Same legend as Figure 4. The shaded areas correspond to 1 S.D. (standard deviation). 

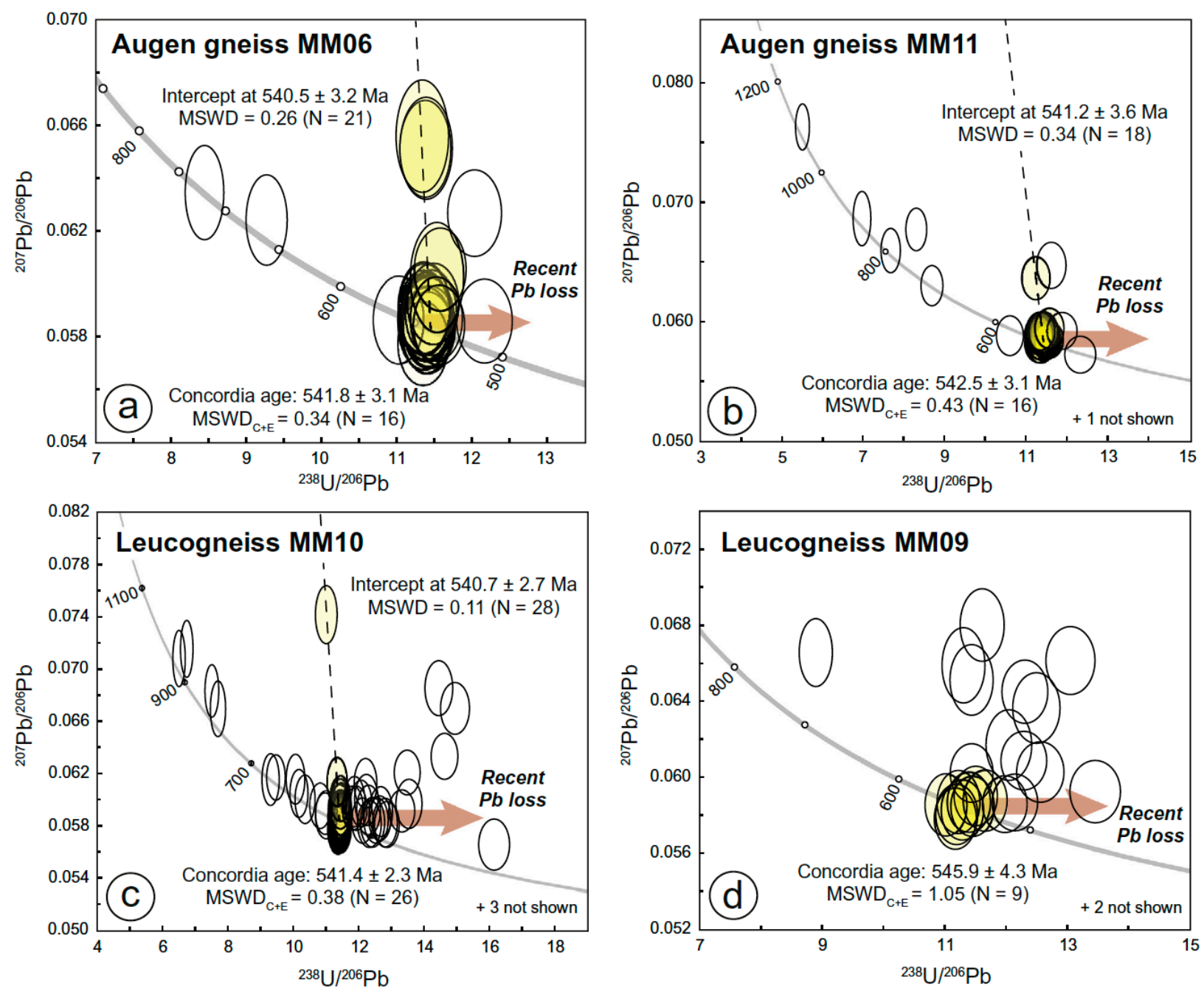

Figure 8: Tera-Wasserburg diagrams $\left({ }^{238} \mathrm{U} /{ }^{206} \mathrm{~Pb}\right.$ vs. $\left.{ }^{207} \mathrm{~Pb} /{ }^{206} \mathrm{~Pb}\right)$ showing zircon data from the Velay Orthogneiss Formation samples investigated in this study. Error ellipses and ages are displayed/quoted at $2 \sigma$ level of uncertainty. Yellowish ellipses are those included in age calculations. 

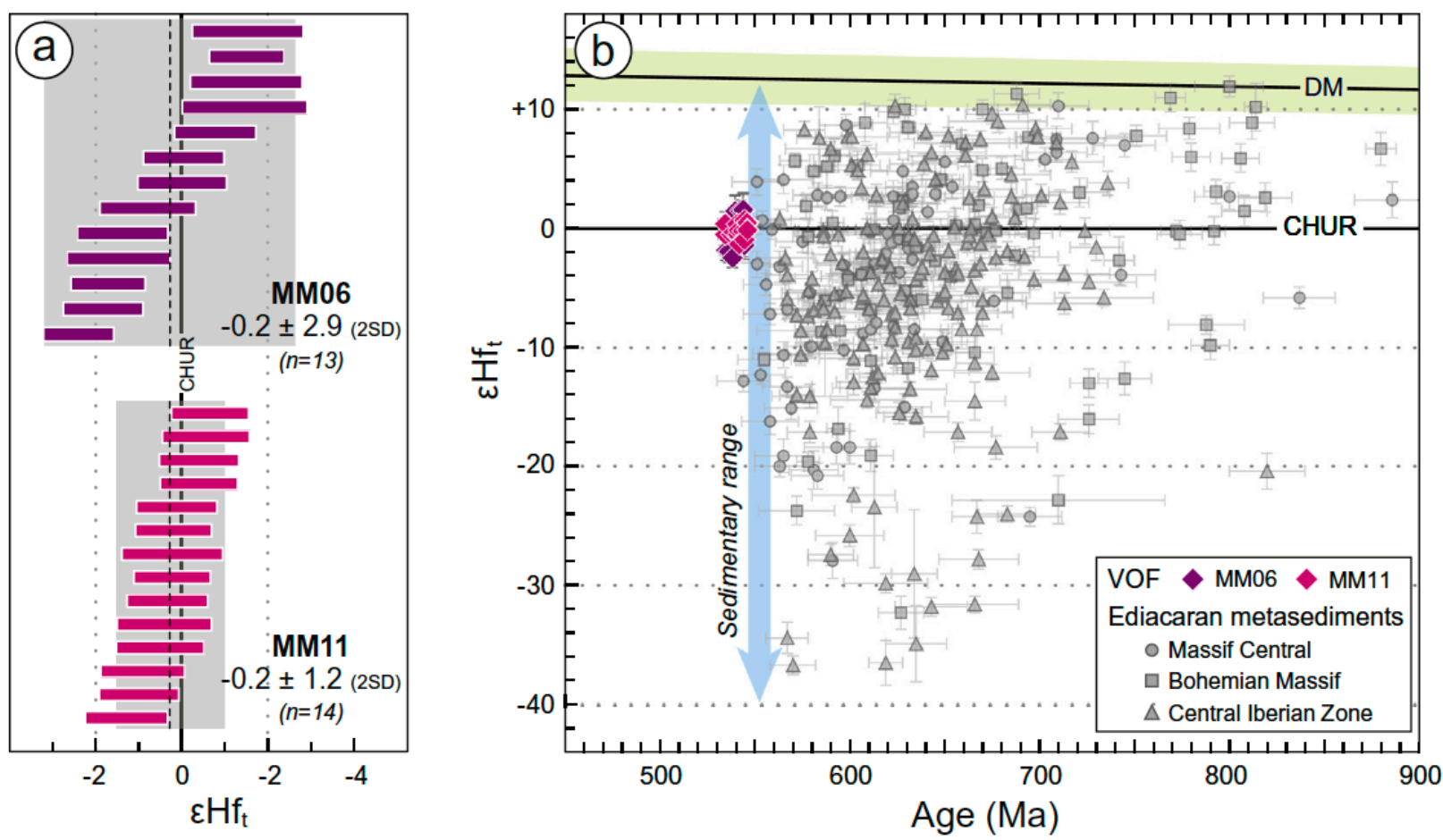

Figure 9: (a) Measured $\varepsilon \mathrm{Hf}(\mathrm{t})$ on magmatic zircon grains and rims from the two investigated samples of augen gneisses of the Velay Orthogneiss Formation (VOF). (b) Zircon $\varepsilon \mathrm{Hf}(\mathrm{t})$ vs. age diagram for the two VOF samples and a compilation of data from detrital zircon in regional Ediacaran metasediments $(n=371)$, regarded as the potential source of the peraluminous magmas from which the VOF protoliths derive. Data from the French Massif Central (Chelle-Michou et al., 2017), the Bohemian Massif (Linnemann et al., 2014) and the Iberian Massif (Orejana et al., 2015; Teixeira et al., 2011). The $\varepsilon H f(t)$ range for the depleted mantle reservoir is bracketed by the models of Naeraa et al. (2012) (lowermost value) and Griffin et al. (2002) (uppermost value). 

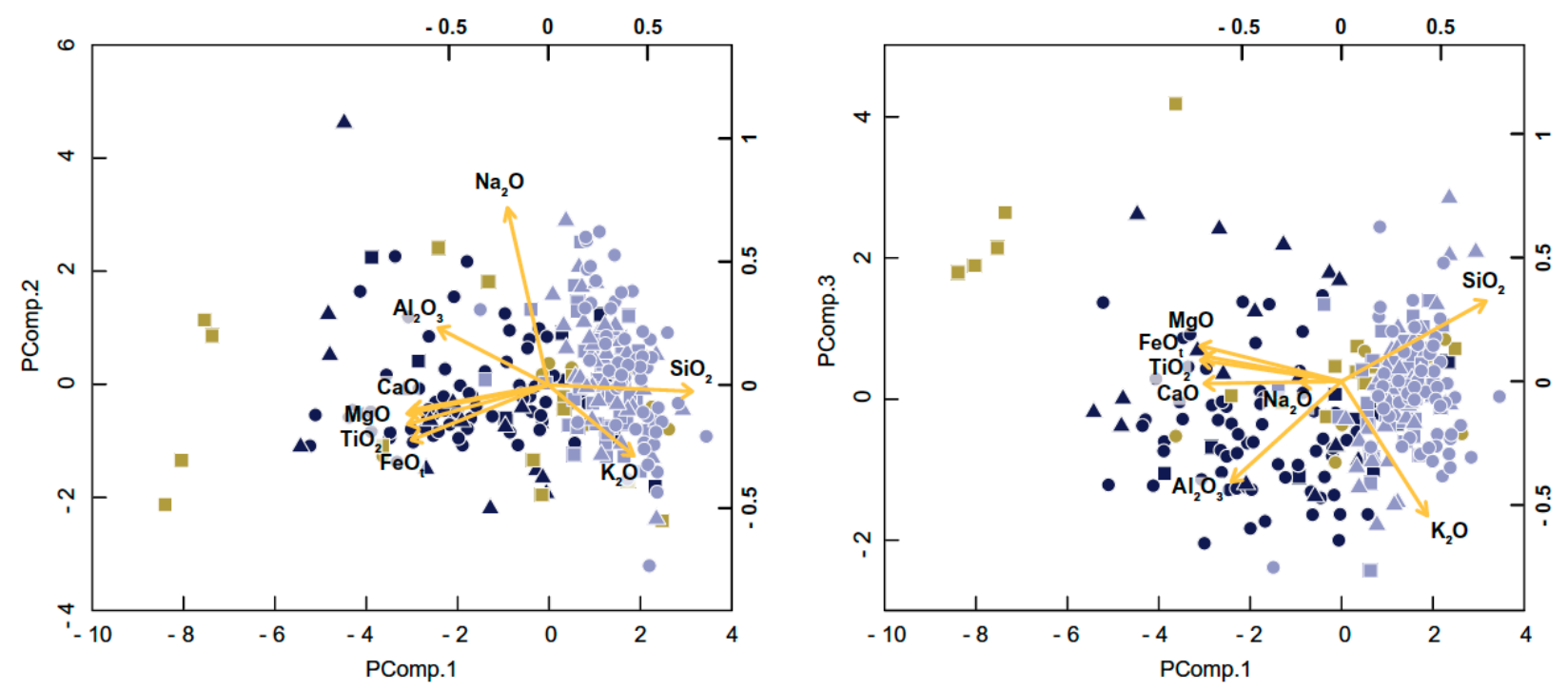

Figure 10: Binary diagrams of the first three principal components calculated for the VOF samples.

Scaled correlation matrix are displayed in bold. Same legend as figure 4. PComp. $1=0.418 \mathrm{SiO}_{2}-$ $0.408 \mathrm{TiO}_{2}-0.319 \mathrm{Al}_{2} \mathrm{O}_{3}-0.397 \mathrm{FeO}_{\mathrm{t}}-0.409 \mathrm{MgO}-0.397 \mathrm{CaO}-0.118 \mathrm{Na}_{2} \mathrm{O}+0.248 \mathrm{~K}_{2} \mathrm{O}$. PComp. $2=-0.183 \mathrm{TiO}_{2}+0.266 \mathrm{Al}_{2} \mathrm{O}_{3}-0.258 \mathrm{FeO}_{\mathrm{t}}-0.134 \mathrm{MgO}-0.116 \mathrm{CaO}+0.829 \mathrm{Na}_{2} \mathrm{O}-$ $0.332 \mathrm{~K}_{2} \mathrm{O}$. PComp. $3=0.417 \mathrm{SiO}_{2}+0.11 \mathrm{TiO}_{2}-0.523 \mathrm{Al}_{2} \mathrm{O}_{3}+0.131 \mathrm{FeO}_{\mathrm{t}}+0.185 \mathrm{MgO}-0.699$ $\mathrm{K}_{2} \mathrm{O}$. 

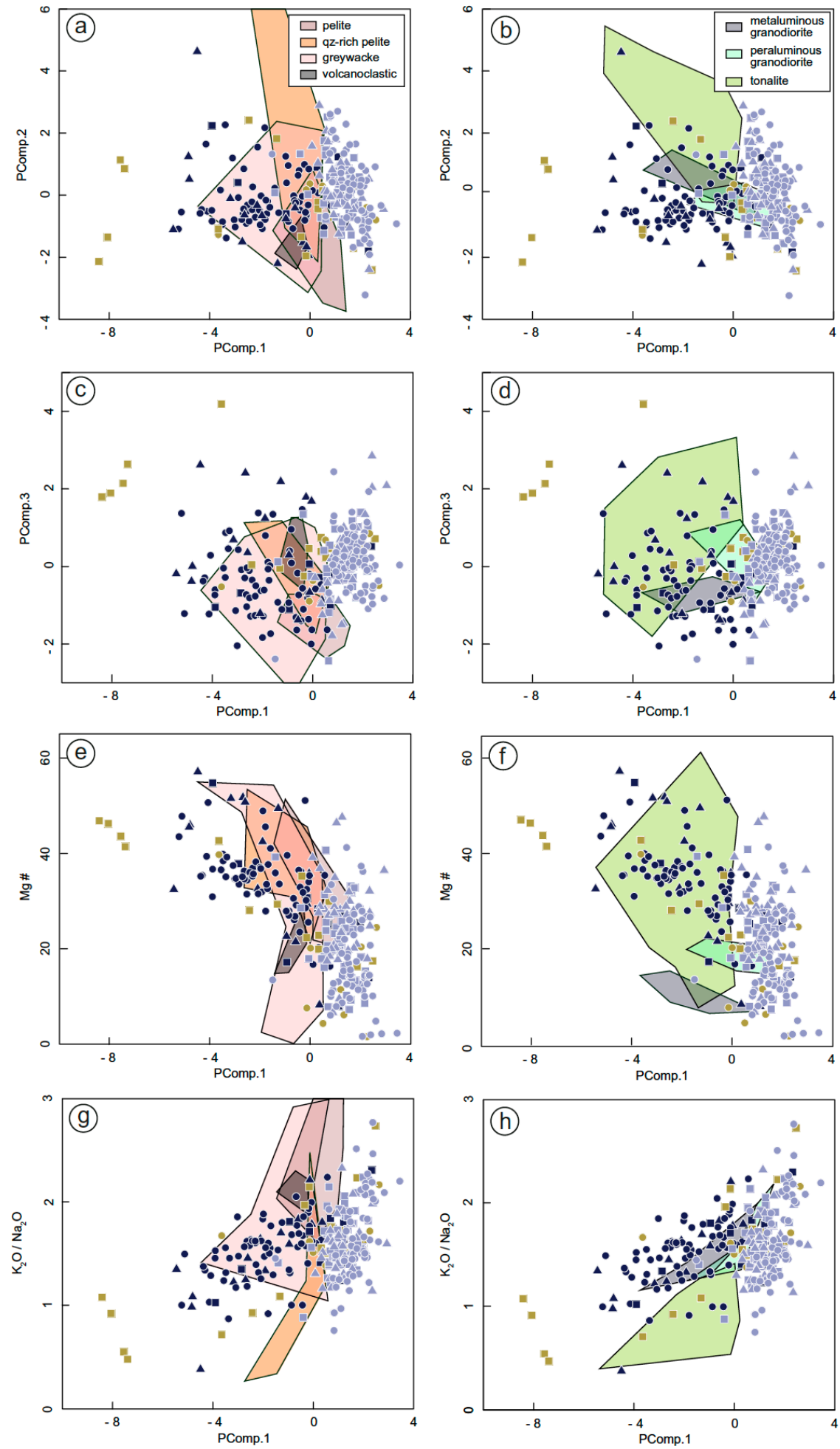

Figure 11: Comparison between VOF samples and experimental melt compositions for a range of crustal sources (see Table 2). Experimental data are projected on the principal component framework. Same legend as figure 4. 

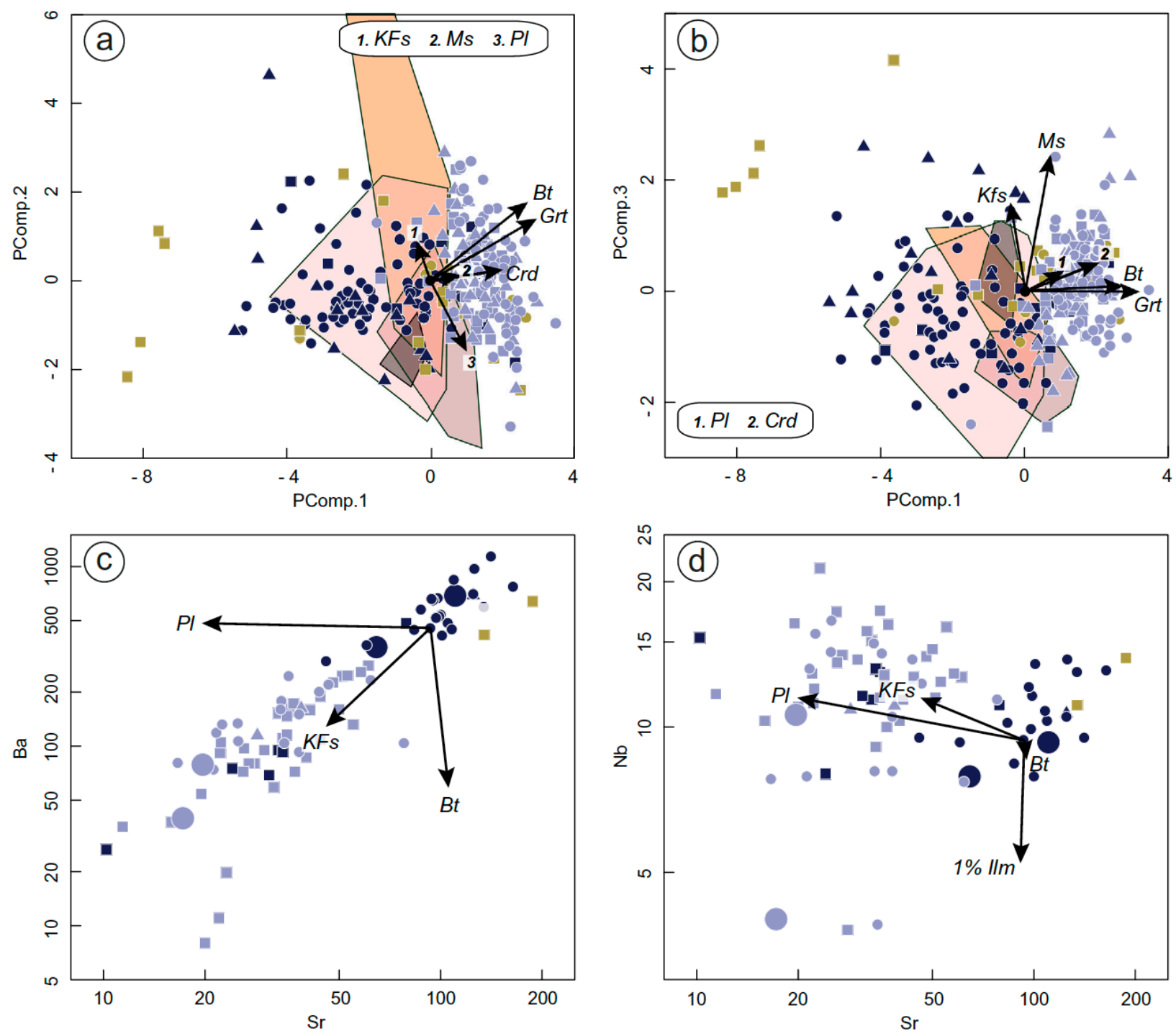

Figure 12: (a) and (b) Major element compositions of fractionated melts. Each arrow shows the composition of a centroid melt $($ P.Comp $1=0)$ after $10 \%$ fractionation of the mentioned mineral phase (and given the composition of the centroid melt). The melt composition in case of a polymineral fractionating assemblage can be graphically estimated by a linear combination of each vector. Generic mineral compositions are from Stevens et al. (2007). (c) and (d) Trace element compositions of fractionated melts. Each arrow depicts the composition of the melt after $20 \%$ (except mentioned value) fractionation of the mineral phase. The list of considered partition coefficients is available as Supp. Material (Table S8). Same legend as figure 4. Larger symbols correspond to dated samples. 


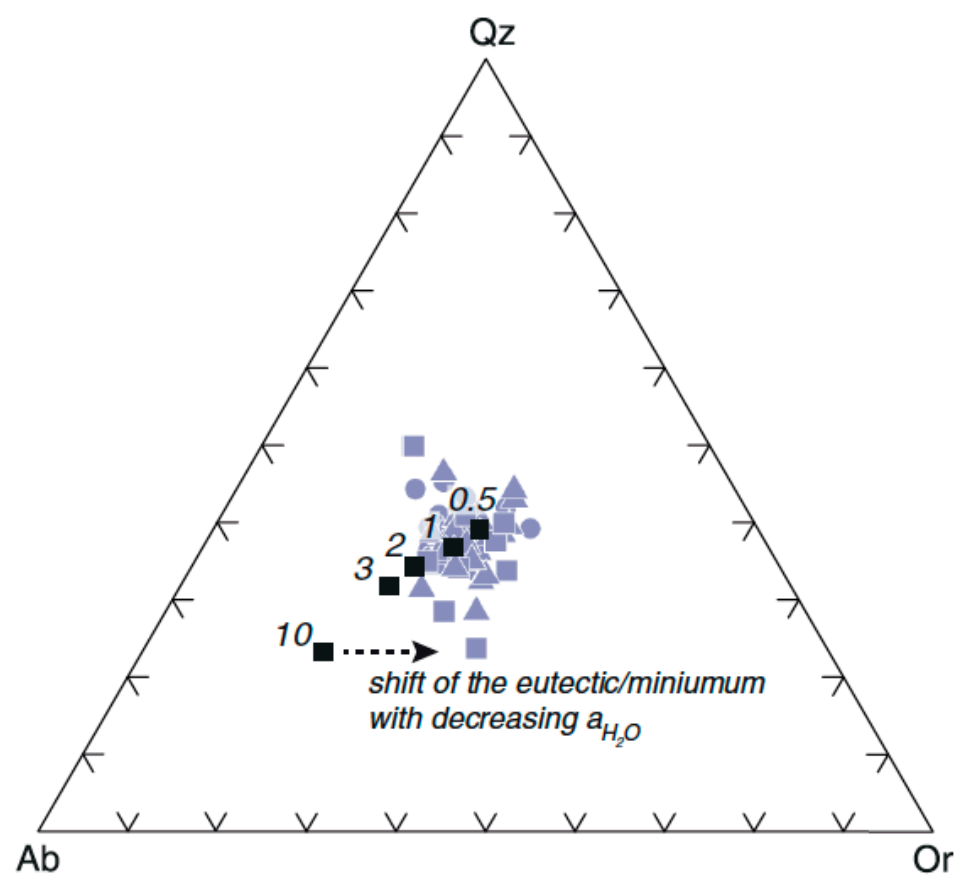

Figure 13: Comparison of leucogneisses corrected normative compositions and experimental data on the $\mathrm{H}_{2} \mathrm{O}$-saturated $\mathrm{Qz}-\mathrm{Ab}$ - Or system at different pressures (numbers in kbars). Minima/eutectics (black squares) as compiled by Blundy and Cashman (2001). Shift of minima/eutectic positions with decreasing water activity from Johannes and Holtz (1996). 


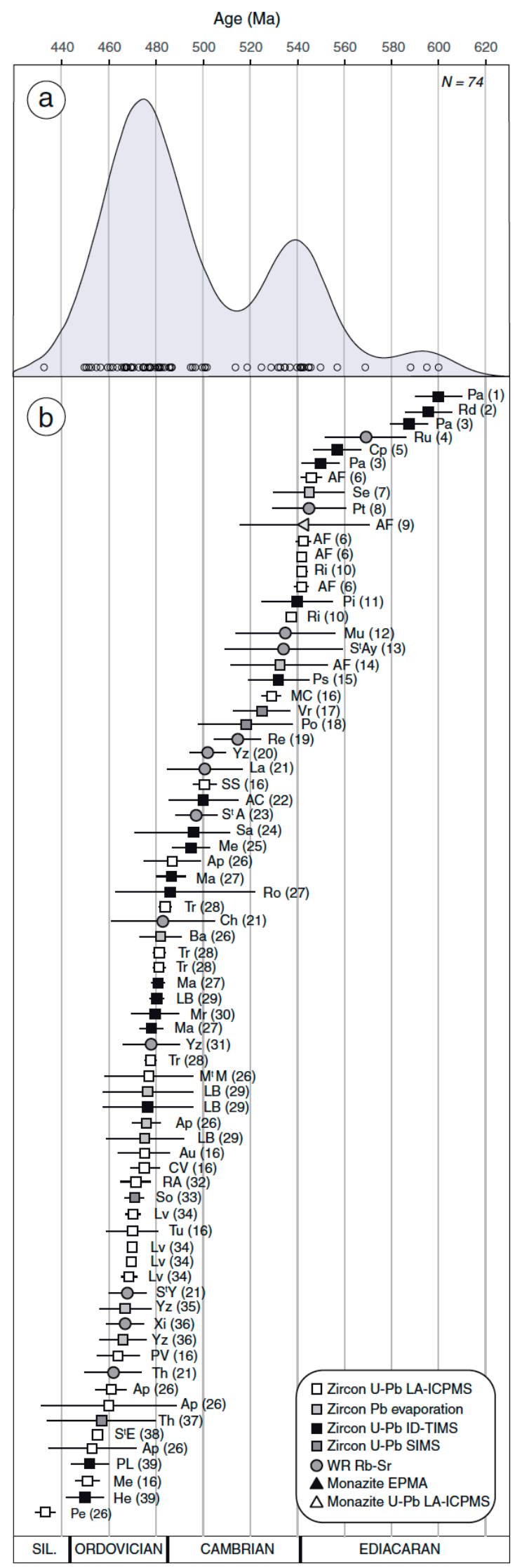

Figure 14: Compilation of available intrusion ages for pre-Variscan volcanic and plutonic rocks in the French Massif Central. (a) Age distribution represented as Kernel Density Estimate, calculated using the DensityPlotter program of Vermeesch (2012); the bandwidth considered is the average $2 \sigma$ error on emplacement ages (12 Ma). (b) Details on available intrusion ages. Abbreviations and references available in Supplementary text. 

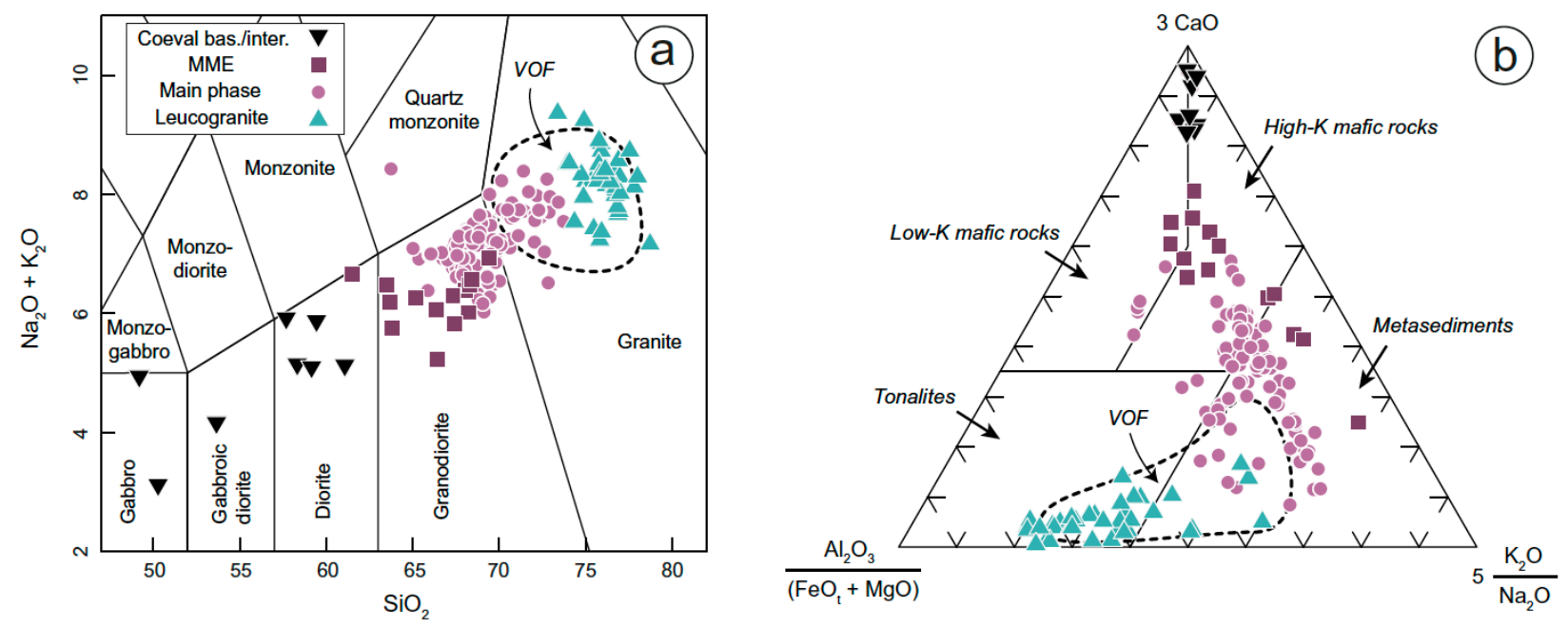

Figure 15: Geochemical comparison between Cadomian granitoids from the Mancellian domain and the VOF ( $>95 \%$ of the samples in the grey field). (a) $\mathrm{Na}_{2} \mathrm{O}+\mathrm{K}_{2} \mathrm{O}$ vs. $\mathrm{SiO}_{2}$ Middlemost's classification diagram (Middlemost, 1994); (b) ternary $\mathrm{CaO}-\mathrm{K}_{2} \mathrm{O} / \mathrm{Na}_{2} \mathrm{O}-\mathrm{Al}_{2} \mathrm{O}_{3} /\left(\mathrm{FeO}_{\mathrm{t}}+\mathrm{MgO}\right)$ diagram (Laurent et al., 2014). The fields represent the composition of melts derived from a range of potential sources. MME: mafic microgranular enclaves. 
Table 1: Nature, mineralogy, sampling localities and coordinates (decimal degrees, WGS84) of the investigated samples of the Velay Orthogneiss Formation together with results of zircon $\mathrm{U}-\mathrm{Pb}$ dating and Lu-Hf isotope measurements performed in this study. Mineral abbreviations from Whitney and Evans (2009).

\begin{tabular}{|c|c|c|c|c|c|c|c|c|c|c|c|c|c|}
\hline Sample & $\begin{array}{l}\text { Velay } \\
\text { domain }\end{array}$ & Locality & Lat. $\mathrm{N}$ & Long. E & Type & Mineralogy $^{\mathrm{a}}$ & $\begin{array}{l}\text { U-Pb } \\
\text { age }^{\text {b }}\end{array}$ & $\pm 2 \sigma$ & $\mathrm{N}_{\mathrm{U}-\mathrm{Pb}}{ }^{\mathrm{c}}$ & $\operatorname{MSWD}_{\mathrm{C}+\mathrm{E}^{\mathrm{d}}}$ & $\varepsilon \mathrm{Hf}(\mathrm{t})^{\mathrm{e}}$ & $\pm 2 \sigma$ & $\mathrm{N}_{\text {Lu-Hf }} \mathrm{f}^{\mathrm{f}}$ \\
\hline MM06 & Arc de Fix & $\mathrm{S}^{\mathrm{t}}$ Privat d'Allier & 44.98811 & 3.68093 & Augen gneiss & $\mathrm{Qz}+\mathrm{Kfs}+\mathrm{Pl}+\mathrm{Bt}+\mathrm{Ms}$ & 541.8 & 3.1 & 16 & 0.34 & -0.2 & 2.9 & 13 \\
\hline MM09 & Arc de Fix & Langogne & 44.69490 & 3.88376 & Leucogneiss & $\mathrm{Qz}+\mathrm{Kfs}+\mathrm{Pl}+\mathrm{Bt}+\mathrm{Ms}+\mathrm{Gt}$ & 545.9 & 4.3 & 9 & 1.05 & & & \\
\hline MM10 & Arc de Fix & Labastide-Puylaurent & 44.56838 & 3.87095 & Leucogneiss & $\mathrm{Qz}+\mathrm{Kfs}+\mathrm{Pl}+\mathrm{Ms}$ & 541.4 & 2.3 & 26 & 0.38 & & & \\
\hline MM11 & Arc de Fix & Col de Meyrand & 44.60534 & 4.07040 & Augen gneiss & $\mathrm{Qz}+\mathrm{Kfs}+\mathrm{Pl}+\mathrm{Bt}+\mathrm{Ms}$ & 542.5 & 3.1 & 17 & 0.43 & -0.2 & 1.2 & 14 \\
\hline
\end{tabular}

${ }^{\text {a }}$ Main mineral phases.

b $\mathrm{U}-\mathrm{Pb}$ Concordia age obtained in the course of this study, in Ma.

c Number of analyses used to calculate the Concordia age.

d MSWD of concordance + equivalence for the displayed Concordia age.

e $\varepsilon \mathrm{Hf}(\mathrm{t})$ measured on magmatic zircons, calculated at the emplacement age of the sample.

${ }^{f}$ Number of Lu-Hf analyses.

Table 2: Experimental melts database used in this study. List of starting materials, pressures and temperatures of melting and associated references (available as Supplementary material).

\begin{tabular}{|c|c|c|c|}
\hline Source rock & Reference & $\mathrm{P}$ (kbar) & $\mathrm{T}\left({ }^{\circ} \mathrm{C}\right)$ \\
\hline Qz-rich pelite & Pickering and Johnson (1998), Patino-Douce and Harris (1998) & $6-10$ & $750-900$ \\
\hline Pelite & Stevens (1995), Patino-Douce and Johnston (1991), Vielzeuf and Holloway (1988) & $5-10$ & $825-900$ \\
\hline Greywacke & Patino-Douce and Harris (1998), Stevens (1995), Patino-Douce and Beard (1996), Montel and Vielzeuf (1997) & $3-10$ & $800-900$ \\
\hline Metaluminous granodiorite & Bogaerts et al. (2006) & $3.7-4.1$ & $775-900$ \\
\hline Peraluminous granodiorite & Holtz and Johannes (1991) & $3-5$ & $700-800$ \\
\hline Tonalite & Watkins et al. (2007) & $6-12$ & $680-900$ \\
\hline Metavolcanoclastic rock & Skjerlie and Johnson (1996) & $10-15$ & $850-900$ \\
\hline
\end{tabular}

